Atmos. Chem. Phys., 19, 14149-14171, 2019

https://doi.org/10.5194/acp-19-14149-2019

(C) Author(s) 2019. This work is distributed under

the Creative Commons Attribution 4.0 License.

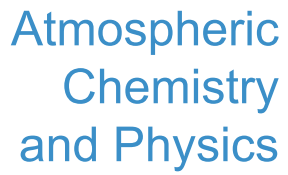

(c) (P)

\title{
Different strategies to retrieve aerosol properties at night-time with the GRASP algorithm
}

\author{
Jose Antonio Benavent-Oltra ${ }^{1,2}$, Roberto Román ${ }^{3}$, Juan Andrés Casquero-Vera ${ }^{1,2}$, Daniel Pérez-Ramírez ${ }^{1,2}$, \\ Hassan Lyamani ${ }^{1,2}$, Pablo Ortiz-Amezcua ${ }^{1,2}$, Andrés Esteban Bedoya-Velásquez ${ }^{2,4}$, Gregori de Arruda Moreira ${ }^{2,5}$, \\ África Barreto ${ }^{3,6,7}$, Anton Lopatin ${ }^{8}$, David Fuertes ${ }^{8}$, Milagros Herrera ${ }^{9}$, Benjamin Torres $^{9}$, Oleg Dubovik ${ }^{9}$, \\ Juan Luis Guerrero-Rascado ${ }^{1,2}$, Philippe Goloub ${ }^{9}$, Francisco Jose Olmo-Reyes ${ }^{1,2}$, and Lucas Alados-Arboledas ${ }^{1,2}$ \\ ${ }^{1}$ Department of Applied Physics, Universidad de Granada, 18071, Granada, Spain \\ ${ }^{2}$ Andalusian Institute for Earth System Research, IISTA-CEAMA, Granada, Spain \\ ${ }^{3}$ Grupo de Óptica Atmosférica (GOA), Universidad de Valladolid, Valladolid, Spain \\ ${ }^{4}$ Sciences Faculty, Department of Physics, Universidad Nacional de Colombia, Medellín, Colombia \\ ${ }^{5}$ Institute of Research and Nuclear Energy (IPEN), São Paulo, Brazil \\ ${ }^{6}$ Cimel Electronique, Paris, France \\ ${ }^{7}$ Izaña Atmospheric Research Center, Meteorological State Agency of Spain (AEMET), Izaña, Spain \\ ${ }^{8}$ GRASP-SAS, Remote Sensing Developments, Université de Lille, 59655, Villeneuve D'ASCQ, France \\ ${ }^{9}$ Laboratoire d'Optique Atmosphérique (LOA), UMR8518 CNRS, Université de Lille, 59655 Villeneuve D'ASCQ, France
}

Correspondence: Jose Antonio Benavent-Oltra (jbenavent@ugr.es)

Received: 28 July 2019 - Discussion started: 5 September 2019

Revised: 4 November 2019 - Accepted: 6 November 2019 - Published: 22 November 2019

\begin{abstract}
This study evaluates the potential of the GRASP algorithm (Generalized Retrieval of Aerosol and Surface Properties) to retrieve continuous day-to-night aerosol properties, both column-integrated and vertically resolved. The study is focused on the evaluation of GRASP retrievals during an intense Saharan dust event that occurred during the Sierra Nevada Lidar aerOsol Profiling Experiment I (SLOPE I) field campaign. For daytime aerosol retrievals, we combined the measurements of the ground-based lidar from EARLINET (European Aerosol Research Lidar Network) station and sun-sky photometer from AERONET (Aerosol Robotic Network), both instruments co-located in Granada (Spain). However, for night-time retrievals three different combinations of active and passive remote-sensing measurements are proposed. The first scheme $\left(N_{0}\right)$ uses lidar night-time measurements in combination with the interpolation of sun-sky daytime measurements. The other two schemes combine lidar night-time measurements with nighttime aerosol optical depth obtained by lunar photometry either using intensive properties of the aerosol retrieved during sun-sky daytime measurements $\left(N_{1}\right)$ or using the Moon aureole radiance obtained by sky camera images $\left(N_{2}\right)$.
\end{abstract}

Evaluations of the columnar aerosol properties retrieved by GRASP are done versus standard AERONET retrievals. The coherence of day-to-night evolutions of the different aerosol properties retrieved by GRASP is also studied. The extinction coefficient vertical profiles retrieved by GRASP are compared with the profiles calculated by the Raman technique at night-time with differences below $30 \%$ for all schemes at 355,532 and $1064 \mathrm{~nm}$. Finally, the volume concentration and scattering coefficient retrieved by GRASP at $2500 \mathrm{~m}$ a.s.l. are evaluated by in situ measurements at this height at Sierra Nevada Station. The differences between GRASP and in situ measurements are similar for the different schemes, with differences below $30 \%$ for both volume concentration and scattering coefficient. In general, for the scattering coefficient, the GRASP $N_{0}$ and $N_{1}$ show better results than the GRASP $N_{2}$ schemes, while for volume concentration, GRASP $N_{2}$ shows the lowest differences against in situ measurements (around 10\%) for high aerosol optical depth values. 


\section{Introduction}

Knowledge of the atmospheric aerosol optical and microphysical properties is important due to their different effects on the Earth-atmosphere radiative budget (IPCC, 2013). The aerosol particles can scatter and absorb solar and terrestrial radiation. The Earth-atmosphere radiative forcing sign (warming or cooling) is sensitive to aerosol optical and microphysical properties and their vertical distribution (e.g. Boucher et al., 2013). In addition, aerosol particles can act as cloud condensation and ice nuclei and, thus, can modify the development, microphysical properties and lifetime of clouds (e.g. Andreae et al., 2004; Boucher et al., 2013). Recent developments in remote sensing have allowed advancing the understanding aerosol globally, but the characteristics of each system do not allow a complete day-to-night characterization, especially in aerosol microphysical properties (e.g. Pérez-Ramírez et al., 2012). Understanding day-tonight aerosol properties from remote-sensing measurements is essential to advances in aerosol dynamics and changes, which eventually will serve to advance our knowledge on aerosol impact on air-quality and climate. Therefore, current efforts are in integrating different measurements that require advancing in the development of retrieval techniques.

During the last 2 decades, global and regional networks have been established to get a comprehensive, quantitative and statistically significant database of atmospheric aerosols. The Aerosol Robotic Network (AERONET; Holben et al., 1998) and East Asian SKYNET (Nakajima et al., 2007) use sun-sky photometers to provide aerosol column-integrated properties with high temporal resolution. These networks use retrieval techniques that allow the characterization of aerosol microphysical properties (e.g. Nakajima et al., 1996; Dubovik and King, 2000). These networks were focused on daytime measurements, but nowadays they are trying to add night-time aerosol measurements derived from lunar photometry. The developments in moon (Berkoff et al., 2011; Barreto et al., 2013, 2016) and star photometry (e.g. PérezRamírez et al., 2011, 2012; Baibakov et al., 2015) allow the acquisition of night-time measurements; however, these measurements are limited in the inversion algorithms to retrieve the aerosol microphysical properties (Pérez-Ramírez et al., 2015; Torres et al., 2017).

Lidar networks such as EARLINET (European Aerosol Research LIdar NETwork; Pappalardo et al., 2014), LALINET (Latin American LIdar NETwork; Guerrero-Rascado et al., 2016; Antuña-Marrero et al., 2017) and MPLNET (Micro-Pulse Lidar Network) (Welton et al., 2002) provide information about aerosol vertical distribution. However, many of the lidar systems operating in these networks are basic lidar systems which only have information on the backscatter elastic signals and only allow the retrieval of the vertical profiles of the aerosol backscatter coefficient $(\beta)$ by the Klett-Fernald method (Fernald et al., 1972; Fernald, 1984; Klett, 1981, 1985) and of the corresponding aerosol extinction $(\alpha)$ coefficient by assuming a constant aerosol extinction-to-backscattering ratio, which is called the lidar ratio (LR). On the other hand, more advanced lidar systems implement the Raman (e.g. Ansmann et al., 1992; Whiteman et al., 1992) technique for independent retrievals of aerosol backscatter and extinction measurements. These multiwavelength lidar measurements allow the use of different inversion algorithms based on the regularization technique to retrieve vertical profiles of aerosol microphysical properties using a $3 \beta+2 \alpha$ configuration, that is, multiwavelength lidar measurements of three backscatter and two extinction coefficients (e.g. Müller et al., 1999; Böckmann, 2001; Veselovskii et al., 2002). Nevertheless, the amount of advanced lidar systems is considerably lower when compared with basic lidar systems; therefore, the independent $\alpha$ and $\beta$ measurements are sparse and mostly limited to night-time. In this context there are a lot of passive and active remote-sensing measurements that alone do not provide enough information to retrieve advanced aerosol microphysical properties. However, integrating all these measurements in an appropriate inversion scheme allows such retrievals and can even complete the number of unknown aerosol optical properties. Such integration is critical for retrieving vertical profiles where the information content for the retrievals is considerably low when compared with classical sun photometer inversion (e.g. Veselovskii et al., 2005). In the framework of EARLINET, different inversion algorithms were developed, such as the LIdar-Radiometer Inversion Code (LIRIC; Chaikovsky et al., 2008, 2016), which uses AERONET retrievals and backscatter elastic signals as input, and the Generalized Aerosol Retrieval from Radiometer and Lidar Combined (GARRLiC; Lopatin et al., 2013) code, which uses sun-sky radiance and backscatter lidar measurements as inputs that make the inversion more consistent (Lopatin et al., 2013).

Of these algorithms, in this study, we use the recently developed Generalized Retrieval of Aerosol and Surface Properties algorithm (GRASP; Dubovik et al., 2011, 2014), which includes the GARRLiC code. GRASP is a versatile and opensource algorithm (https://www.grasp-open.com/, last access: 1 July 2019) based in the concept of the Dubovik and King (2000) algorithm which has been used successfully by AERONET during the last decades. The GRASP algorithm is divided into two main independent modules: the forward model and numerical inversion modules. The forward model is based on radiative transfer and aerosol models, and it is a convenient tool for sensitivity and tuning studies (Dubovik et al., 2014; Torres et al., 2017). The numerical inversion module is the main part of the core program, which includes general mathematical operations based on the multi-term least square method (LSM) concept (Dubovik and King, 2000; Dubovik, 2004). The GRASP versatility allows the retrieval of aerosol properties through the combination of measurements from different instruments both column-integrated and vertically resolved. In fact, GRASP 
was successfully utilized for the retrieval of the aerosol properties using different configurations and measurements, such as polar nephelometer data (Espinosa et al., 2017), satellite remote-sensing data (Kokhanovsky et al., 2015; Dubovik et al., 2019), aerosol optical depth (AOD) and sky radiances (including polarization) (Fedarenka et al., 2016), spectral AOD and sky camera images (Román et al., 2017a), only spectral AOD (Torres et al., 2017), and the combination of aerosol optical depth (AOD), sky radiances and elastic lidar (Lopatin et al., 2013; Benavent-Oltra et., 2017) or ceilometer profiles (Román et al., 2018). The aerosol properties retrieved by GRASP aerosol profiles have been used as input to radiative transfer models (Granados-Muñoz et al., 2019), to evaluate dust forecast models (Tsekeri et al., 2017) or to be assimilated in global models (Chen et al., 2018).

In this framework, the main objective of this paper is to propose and explore different and novel strategies for the retrieval of vertically resolved aerosol properties at night-time using the GRASP algorithm combining remote-sensing measurements as input data. Another goal is to quantify the accuracy of the retrieved night-time aerosol properties obtained by these strategies, classified into three schemes and using as reference independent aerosol measurements and products. To that end, the recent developments on lunar photometry, which allows us to derive the night-time AOD from a lunar photometer (Barreto et al., 2013, 2016) and the new studies with sky camera images, which allow us to obtain the normalized sky radiance from the lunar aureole (Román et al., 2017a), open the possibility to explore the use of the GRASP algorithm combining these night-time measurements with elastic lidar data to study night-time microphysical and optical aerosol properties.

The paper structure is as follows. Sects. 2 and 3 give a brief description of the experimental site, instrumentation used and the dust event that occurred during the Sierra Nevada Lidar aerOsol Profiling Experiment I (SLOPE I) campaign. The different schemes used in GRASP to retrieve the aerosol properties both during the day and at night-time are described in Sect. 4. In Sect. 5, the assessment of the aerosol columnintegrated and vertically resolved properties retrieved by GRASP is discussed both during the day and at night-time. Finally, the conclusions are given in Sect. 6 .

\section{Experimental site and instrumentation}

\subsection{Andalusian Global ObseRvatory of the Atmosphere}

The paper is mainly focused on the city of Granada (Spain). Granada is located in the Western Mediterranean basin and it is frequently affected by long-range transport of Saharan dust (Lyamani et al., 2005; Fernández et al., 2019; Soupiona et al., 2019) and biomass burning, both from near sources (Alados-Arboledas et al., 2011) and those at large distances (e.g. Ortiz-Amezcua et al., 2017; Sicard et al., 2019). The main local sources of anthropogenic aerosols are road traffic and heating systems during the winter season (Lyamani et al., 2010). Under strong anticyclone conditions, the orographic situation with the city situated in a basin surrounded by mountains makes ventilation processes difficult and favours aerosol stagnation (Patrón et al., 2017).

The experimental measurements used in this study were collected in the AGORA (Andalusian Global ObseRvatory of the Atmosphere) in Granada. AGORA deployed instrumentation at three different stations at different altitudes. The principal station (UGR) is located in the Andalusian Institute for Earth System Research/IISTA-CEAMA in Granada city, where active and passive remote-sensing instrumentation operated. The other two stations are in the Sierra Nevada: Cerro Poyos Station $\left(37.11^{\circ} \mathrm{N}, 3.49^{\circ} \mathrm{W} ; 1820 \mathrm{~m}\right.$ a.s.l.) and Sierra Nevada Station (SNS; $37.10^{\circ} \mathrm{N}, 3.39^{\circ} \mathrm{W} ; 2500 \mathrm{~m}$ a.s.l.). In this study, we used the in situ measurements from SNS, which is located about $25 \mathrm{~km}$ away (horizontally) from UGR. The measurements of SNS can allow the characterization of regional and long-range transport episodes and the validation of inversion algorithms used to retrieve aerosol optical and microphysical properties. The altitude difference between UGR and SNS $(\sim 1.8 \mathrm{~km})$ and the short horizontal distance make the correlative measurements between both sites ideal in our objective of evaluating different GRASP scheme retrievals.

The measurements used in this work were acquired in the framework of the SLOPE I campaign. SLOPE I took place at AGORA from May to September 2016 with the objective validating the vertically resolved aerosol properties retrieved from the combination of active and passive remote-sensing measurements by in situ measurements on the surrounding high mountain area. In this regard, several studies have been done using SLOPE I database: day-to-night evolution of the planetary boundary layer (de Arruda Moreira et al., 2018) and its turbulence behaviour (de Arruda Moreira et al., 2019), aerosol hygroscopic growth (Bedoya-Velásquez et al., 2018), evaluation of the aerosol properties during the daytime retrieved by GRASP combining a ceilometer and sun-sky photometer measurements (Román et al., 2018), and the characterization of the angular scattering of the Sahara dust aerosol by means of polar nephelometry (Horvath et al., 2018). Thus, SLOPE I is ideal for our purposes of studying day-to-night aerosol microphysical properties retrievals.

\subsection{Remote-sensing measurements}

The measurements of the remote-sensing instrumentation of UGR are used as input data in the different GRASP schemes (see Sect. 4). One of these instruments is a multiwavelength Raman lidar (LR331D400, Raymetrics S.A.), which has been included in EARLINET since 2005 and contributes to the ACTRIS (Aerosols, Clouds, and Trace gases Research InfraStructure Network) research infrastructure. It is composed 
of a pulsed Nd:YAG laser that emits at $1064 \mathrm{~nm}(110 \mathrm{~mJ}$ per pulse), $532 \mathrm{~nm}(65 \mathrm{~mJ}$ per pulse $)$ and $355 \mathrm{~nm}(60 \mathrm{~mJ}$ per pulse) by means of the second and third harmonic generators. The receiving system has seven channels: three to measure the backscatter signal at emission wavelengths plus one additional channel to measure the cross-polarized signal at $532 \mathrm{~nm}$, two channels at 387 and $607 \mathrm{~nm}$ for the detection of Raman scattering from $\mathrm{N}_{2}$, and an additional channel to detect the Raman scattering from water vapour at $408 \mathrm{~nm}$. Due to incomplete overlap, atmospheric information up to $500 \mathrm{~m}$ above the system is limited (Navas-Guzmán et al., 2011). A detailed description of this multiwavelength Raman lidar system may be found in Guerrero-Rascado et al. (2008, 2009).

Co-located with the lidar system, a sun-sky-lunar photometer Cimel CE318-T (Cimel Electronique), included in the AERONET network, has been making daytime and nighttime measurements since March 2016. This photometer is equipped with a filter wheel (nine narrow filters) covering the spectral range between 340 and $1640 \mathrm{~nm}$. During the daytime, the sun-sky-lunar photometer performs measurements of sky radiance but also direct solar irradiance, which is used to derive the AOD; both kinds of measurements can be used to retrieve detailed aerosol properties such as the particle size distribution, complex refractive index (CRI) and singlescattering albedo (SSA) (Nakajima et al., 1996; Dubovik et al., 2006). This photometer is annually calibrated following the AERONET methodology by ACTRIS/AERONETEurope, the European branch of AERONET. Furthermore, this photometer has the capacity to measure the solar radiation reflected by the Moon during the night-time, providing valuable information on atmospheric aerosols throughout the whole day. Therefore, the sun-sky-lunar photometer provides the AOD at night-time between the first and third Moon quarters (Barreto et al., 2013, 2019). The calibration of the CE318-T for AOD calculation at night-time has been done by the lunar-Langley calibration method explained by Barreto et al. (2019). More details of the sun-sky-lunar photometer Cimel CE318-T and its operational functionalities are described by Barreto et al. (2016).

Furthermore, we used a sky camera SONA (Sistema de Observación de Nubosidad Automático - Automatic Cloud Observation System), which provides hemispherical sky images during the day and at night (González et al., 2012). This system is composed of a CCD (charge-coupled device) camera with a fisheye lens providing RGB images, the effective wavelengths of which correspond to 469, 533 and $608 \mathrm{~nm}$ (Román et al., 2017a) for night scenarios. It was configured to take multi-exposure sequences of sky images. These sequences are used to obtain a high dynamic range (HDR) image (one every $5 \mathrm{~min}$ ) which allows us, after some correction processes, to obtain the normalized radiances at lunar almucantar points (up to $20^{\circ}$ in azimuth from the Moon) at the three effective wavelengths as shown by Román et al. (2017a). Sky cameras usually present a low signal-tonoise ratio. Thus, to calculate the Moon radiances from sky camera images, we need cases with high values of AOD (to enhance the scattered Moon signal in the aureole) and high Moon extraterrestrial irradiance, which restrict data availability to the period between the first and last Moon quarters (Román et al., 2017a). In addition, in this work we applied a threshold to use the Moon radiance calculated from sky camera images: (1) the Moon zenith angle must be lower than $70^{\circ} ;(2)$ a minimum of 18 sky radiances with azimuth angles between 3 and $20^{\circ}$ must be available for each effective wavelength of the sky camera. A detailed explanation of the configuration, corrections and products obtained by this camera is presented in Román et al. (2017a, b).

\subsection{In situ measurements}

The in situ measurements collected at SNS are used to assess the aerosol properties, such as scattering coefficient $\left(\sigma_{\text {sca }}\right)$ and volume concentration (VC) retrieved by the GRASP algorithm. The integrating nephelometer (model TSI 3563) measures the particle light scattering coefficients at three wavelengths $(450,550$ and $700 \mathrm{~nm})$ with 5 min temporal resolution. A quartz-halogen lamp equipped with a built-in elliptical reflector illuminates over an angle of 7 to $170^{\circ}$ the air sample (particle + gas) extracted by a small turbine blower at a constant flow of $30 \mathrm{~L} \mathrm{~min}^{-1}$. The nephelometer measurements underestimate the scattering and backscattering coefficients due to the limits of the angular integration of the scattered light since a part of forward $\left(0-7^{\circ}\right)$ and backward $\left(170-180^{\circ}\right)$ signals are not measured. Nephelometer data have been corrected for truncation and non-Lambertian illumination errors using the method described by Anderson and Ogren (1998).

The scanning mobility particle sizer (SMPS) composed of an electrostatic classifier (TSI Mod. 3080) and a condensation particle counter (CPC; TSI Mod. 3772) measures the sub-micron particle number size distribution within the 12 $615 \mathrm{~nm}$ particle mobility diameter range with 5 min temporal resolution. Aerosol and sheath flow rates were 1.0 and $5.0 \mathrm{~L} \mathrm{~min}^{-1}$, respectively. SMPS data have been corrected for internal diffusion losses and multiple charges with the AIM software (version 9.0.0, TSI, Inc., St Paul MN, USA). Following calibration procedures, uncertainty in the measured particle size distribution is within $10 \%$ and $20 \%$ for the size range of 20-200 and 200-800 nm, respectively (Wiedensohler et al., 2012). In addition, the coarse particle number size distribution within the $0.5-20 \mu \mathrm{m}$ aerodynamic diameter range was measured by an aerodynamic particle sizer (APS; TSI Mod. APS-3321). The APS measures number aerosol concentrations up to 1000 particles per centimetre with coincidence errors inferior to $5 \%$ and $10 \%$ at 0.5 and $10 \mu \mathrm{m}$ diameters. From these measurements, aerosol volume concentrations were obtained in the $0.05-10 \mu \mathrm{m}$ radius range with the 5 min time resolution. For that, a $Q$ value $=1$ has been assumed for conversion from aerodynamic to mobility size distribution (Sorribas et al., 2015). 
NOAA HYSPLIT MODEL

(a) Backward trajectories ending at 20:00 UTC 18 Jul 2016 GDAS Meteorological Data

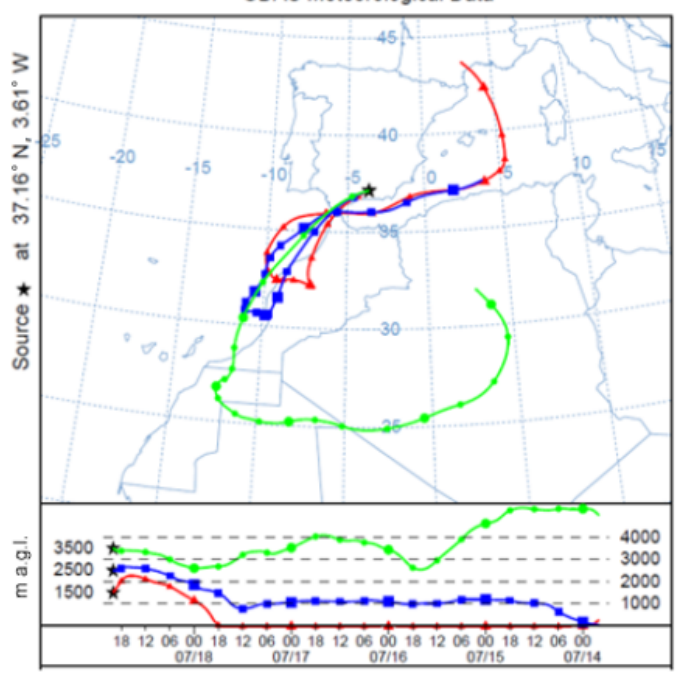

NOAA HYSPLIT MODEL

(b) Backward trajectories ending at 19:00 UTC 20 Jul 2016 GDAS Meteorological Data

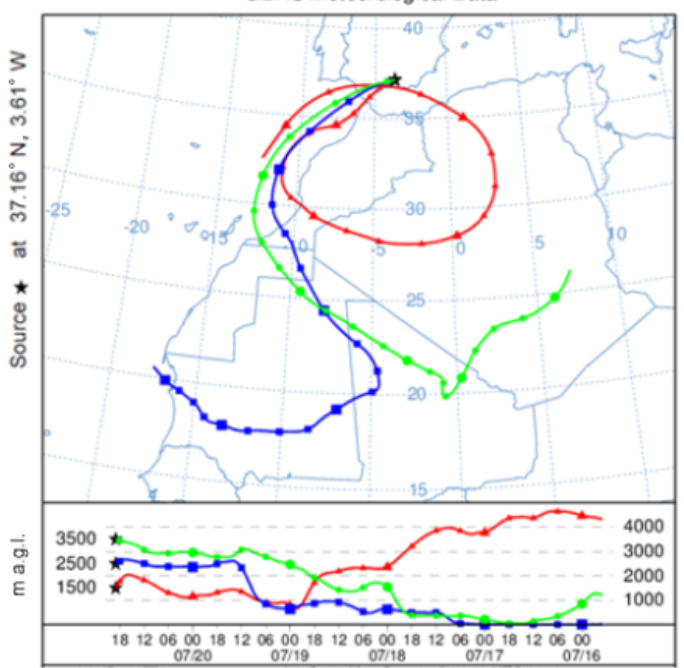

Figure 1. Five-day backward trajectories computed using HYSPLIT reaching Granada at 20:00 UTC on 18 July (a) and at 19:00 UTC on 20 July 2016 (b).

\section{Dust event during SLOPE I campaign}

This work focuses on an intense dust event that reached the south-east of the Iberian Peninsula during the SLOPE I field campaign from 18 to 21 July 2016. The analysis of $5 \mathrm{~d}$ backward trajectories (Fig. 1) computed by the HYSPLIT model (Hybrid Single-Particle Lagrangian Integrated Trajectory; Stein et al., 2015; Rolph, 2016) indicate that the air masses that arrived at Granada came from a south-western direction on 18 and 21 July 2016. These air masses from the Sahara area passed along south Morocco and the Moroccan coast before reaching Granada. As shown hereafter, these Saharan air masses transported large amounts of Saharan dust particles to the study area.

Figure $2 \mathrm{a}$ and $\mathrm{b}$ show the day and night-time AOD at $440 \mathrm{~nm}\left(\mathrm{AOD}_{440}\right)$ and the Ångström exponent (AE), computed with $\mathrm{AOD}$ at 440 and $870 \mathrm{~nm}\left(\mathrm{AE}_{440-870}\right)$, at UGR provided by AERONET. This figure reveals two different periods throughout the dust event with different $\mathrm{AOD}_{440}$ values: the first period from 18 to 19 July (hereinafter the $P_{1}$ period) with a mean value of $0.50 \pm 0.03$ and the second period from 20 to 21 July (hereinafter the $P_{2}$ period) with a mean value ( \pm standard deviation) of $0.94 \pm 0.08$. These $\mathrm{AOD}_{440}$ values obtained in $P_{1}$ and $P_{2}$ periods are 2 and 4 times higher than the $\mathrm{AOD}_{440}$ mean value reported by Pérez-Ramírez et al. (2016) for desert dust intrusions over Granada, which make this Saharan dust event extraordinary. However, the $\mathrm{AE}_{440-870}$ values show a smooth behaviour with no significant variations around the mean value of $0.17 \pm 0.03$, which is typical of Saharan dust intrusions over the Granada region (e.g. Lyamani et al., 2006; Guerrero-Rascado et al., 2008, 2009; Pérez-Ramírez et al., 2016).
Figure $2 \mathrm{c}$ and $\mathrm{d}$ show the day-to-night temporal evolution of $\sigma_{\mathrm{sca}}$ at $550 \mathrm{~nm}$ and the total $\mathrm{VC}$ obtained from in situ instrumentation throughout the dust event at the high mountain SNS, respectively. Clearly, both VC and $\sigma_{\text {sca }}$ show a continuous increase from the minimum on 18 July ( $~$ $50 \mathrm{Mm}^{-1}$ for $\sigma_{\text {sca }} ; \sim 40 \mu \mathrm{m}^{3} \mathrm{~cm}^{-3}$ for VC) to the maximum values reached early in the morning of 21 July $\left(\sim 350 \mathrm{Mm}^{-1}\right.$ for $\sigma_{\text {sca }} ; \sim 250 \mu \mathrm{m}^{3} \mathrm{~cm}^{-3}$ for VC). This large increase on these two extensive aerosol properties, especially on 2021 July, is associated with the transport of Saharan dust particles and shows the drastic impact of this Saharan dust event on the aerosol load at the remote SNS.

Figure 3 shows the temporal evolution of the rangecorrected signal (RCS) at $532 \mathrm{~nm}$ from the lidar system at UGR; it points out detailed layer evolution during this Saharan dust event. The dashed horizontal purple line shows the height of the SNS mountain station. This figure reveals important variability in the layer structures of the atmosphere. On 18 July, in the evening, two different and decoupled aerosol layers are observed: one at $4 \mathrm{~km}$ a.s.l. and the other one near the surface, approximately up to $1.2 \mathrm{~km}$ a.s.l. However, during the night of 18-19 July the upper aerosol layer gradually went down until it mixed with the surface aerosol layer, causing any clear vertical layering to fade away. On the following day, particularly after 08:00 UTC, two different aerosol layers are observed again. From the afternoon on 19 July to noon on 20 July, clouds were present over the site, and hence the RCS data obtained during this period are excluded from further analysis. After restarting lidar measurements, on 20 July a decoupled aerosol layer at approximately $4 \mathrm{~km}$ a.s.l. is observed again; this layer also gradually went down until it mixed with the boundary layer early 
(a)
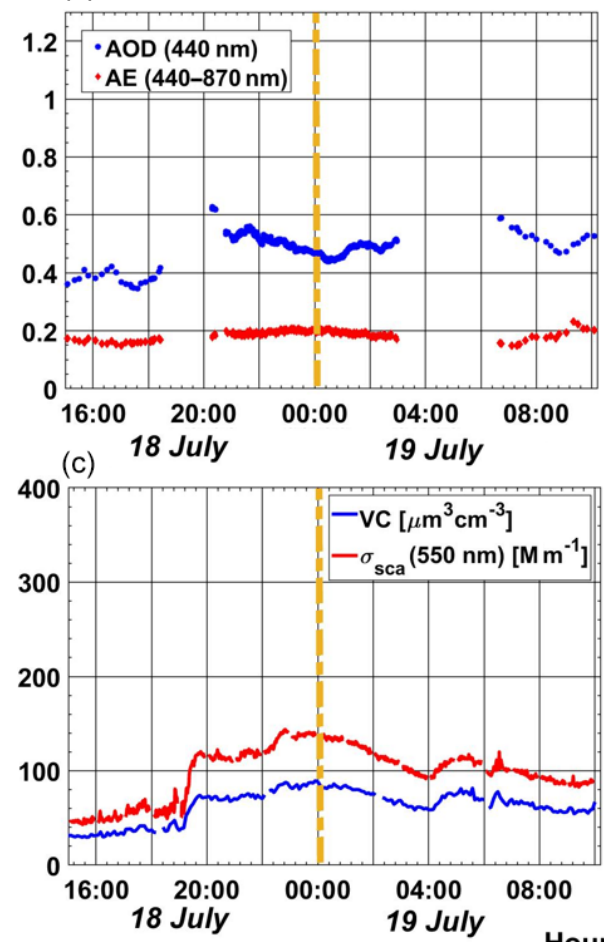

(b)

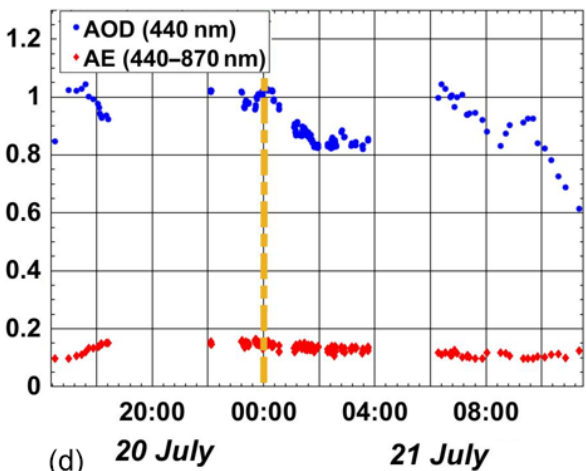

(d) 20 July

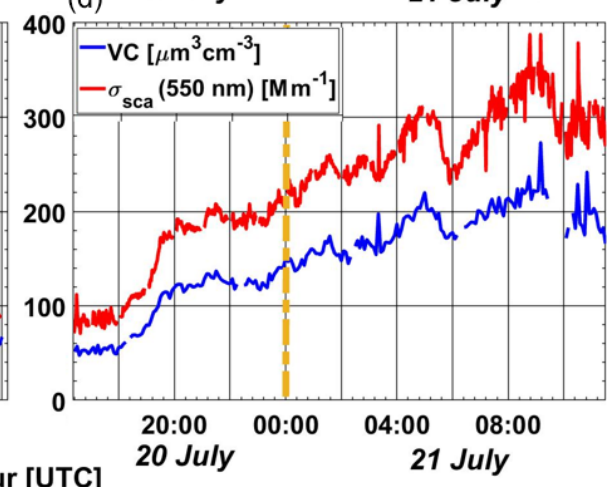

Figure 2. Day-to-night evolution of the AOD at $440 \mathrm{~nm}$ (blue) and AE (440-870 nm) (red) obtained at UGR from 18 to 19 July 2016 (a) and from 20 to 21 July 2016 (b). Day-to-night temporal evolution of the total volume concentration (VC) and the scattering coefficient $\left(\sigma_{\text {sca }}\right)$ at $550 \mathrm{~nm}$ measured at SNS from 18 to 19 (c) and from 20 to 21 (d) July 2016.

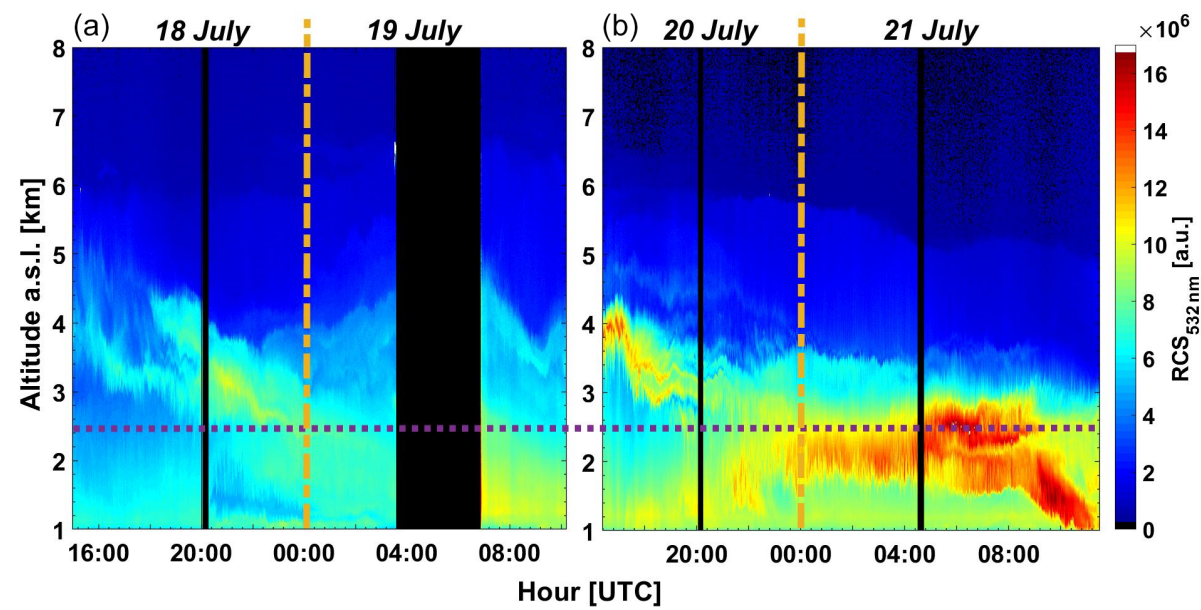

Figure 3. Temporal evolution of the lidar range-corrected signal at $532 \mathrm{~nm}$ from 18 to 19 (a) and from 20 to 21 (b) July 2016 . The purple horizontal line indicates the SNS altitude.

at night. But the most remarkable observation in this period is the very different structure observed after 04:00 UTC on 21 July when two decoupled layers at $\sim 2-3 \mathrm{~km}$ a.s.l. altitude appeared. Later, in the morning of 21 July, the upper layer collapsed and mixed with the surface layer.

The multi-layer aerosol evolution revealed in Fig. 3 agrees with that observed before in $\mathrm{AOD}_{440}$ and $\mathrm{AE}_{440-870}$ val- ues and with in situ measurements at SNS. Actually, the increase in the intensity of RCS on 20 July agrees with the increase in AOD. Moreover, the increase in RCS at the altitude of $2500 \mathrm{~m}$ a.s.l. coincides with the increase in $\sigma_{\text {sca }}$ and VC measured in situ at SNS. The collapse of the layer at $2500 \mathrm{~m}$ a.s.1. after 08:00 UTC on 21 July also agrees with the decrease in $\sigma_{\text {sca }}$ and VC at SNS. 
Table 1. Data set used as input in the GRASP algorithm for day and night-time retrievals. The aerosol size distribution used in each scheme and the number of the converging retrievals obtained during the first $\left(P_{1}\right)$ and second $\left(P_{2}\right)$ periods.

\begin{tabular}{|c|c|c|c|c|c|c|c|}
\hline & \multicolumn{3}{|c|}{ Measurements and wavelengths } & \multirow{2}{*}{$\begin{array}{l}\text { CRI and } \\
\text { sphericity }\end{array}$} & \multirow[t]{2}{*}{ SD model } & \multicolumn{2}{|c|}{ No. retrievals } \\
\hline & AOD & Sky radiance & RCS & & & $P_{1}$ & $P_{2}$ \\
\hline$D$ & \multirow{2}{*}{\multicolumn{2}{|c|}{$440,675,870$ and $1020 \mathrm{~nm}$}} & \multirow{4}{*}{$\begin{array}{l}355,532 \text { and } \\
1064 \mathrm{~nm}\end{array}$} & Retrieved & 25 bins & 10 & 7 \\
\hline$N_{0}$ & & & & Retrieved & 25 bins & 8 & 16 \\
\hline$N_{1}$ & $\begin{array}{l}440,675,870 \\
\text { and } 1020 \mathrm{~nm}\end{array}$ & $x$ & & Fixed & $\begin{array}{l}\text { Bimodal } \\
\text { lognormal }\end{array}$ & 9 & 11 \\
\hline$N_{2}$ & $\begin{array}{l}469,675,870 \\
\text { and } 1020 \mathrm{~nm}\end{array}$ & $\begin{array}{l}469,533 \text { and } \\
608 \mathrm{~nm}\end{array}$ & & Retrieved & 25 bins & 6 & 7 \\
\hline
\end{tabular}

Given coherence among all measurements, we can affirm that the Saharan dust affected a wide area, and measurements in UGR and SNS are both representative of such event. Thus, the conditions of this dust event allow the evaluation of vertical and columnar aerosol optical and microphysical properties retrieved by the GRASP algorithm both during the day and at night-time.

\section{GRASP retrieval schemes}

In this section, we present in four schemes the different strategies used in the GRASP algorithm for retrieving continuous day and night-time atmospheric aerosol properties in both column-integrated and vertical profiles. For daytime retrievals (denoted as $D$ ), the scheme used in GRASP is that proposed by Lopatin et al. (2013), which used both lidar and sun-sky photometer measurements as input data. On the other hand, we have proposed three different schemes to retrieve the aerosol properties during the night-time; each scheme can be used depending on the available instrumentation and the conditions of the event.

The lidar data use in each retrieval (both for day and nighttime retrieval) corresponds to preprocessed $30 \mathrm{~min}$ averages of the raw signals for each wavelength. This preprocessing includes background noise subtraction and altitude correction, but other corrections are also applied as overlap correction, analog and photon-counting signal gluing, and depolarization correction. To reduce the number of retrieved parameters and to remove the noise in lidar signals at higher altitudes, a logarithmical altitude or range scale with 60 points between minimum and maximum altitudes is used as in Lopatin et al. (2013). More details of lidar data preprocessing are described in Lopatin et al. (2013). In addition to the lidar signal measurements, each scheme uses different input data from different instrumentation, and hence the retrieval strategies and configurations differ between schemes. These configurations are summarized in Table 1 and described in the following subsections.

\subsection{Daytime scheme}

As commented, for scheme $D$ the set of measurements used as input in GRASP are those recommended by Lopatin et al. (2013): the normalized lidar RCS at 355, 532 and $1064 \mathrm{~nm}$ and AERONET sun-sky radiances measurements at 440, 675,870 and $1020 \mathrm{~nm}$. Both daytime AOD and sky radiances used in this work are Version 2 Level 2.0 provided by AERONET from the Cimel CE318-T photometer.

\subsection{Night-time schemes}

\subsection{1 $N_{0}$}

The first night-time scheme ( $N_{0}$ scheme) used in GRASP assumes that there is no change in the aerosol columnintegrated extensive and intensive properties throughout the night. As AOD and sky radiance measurements during the night-time are still very scarce, this scheme combines the night-time elastic lidar measurements with the closest sunsky measurements registered the day before or the day after. Thus, the $N_{0}$ scheme uses the night-time RCS measured by lidar at 355, 532 and $1064 \mathrm{~nm}$ combined with the closest daytime measurements of AOD and sky radiances at 440, 675, 870 and $1020 \mathrm{~nm}$. This scheme offers the possibility to retrieve aerosol vertical properties in stations where night-time photometer measurements are not available, but it should only be applied when the aerosol load and type is similar throughout the night-time.

\subsection{2 $\quad N_{1}$}

Currently, night-time AOD measurements, taken with the recently developed sun-sky-lunar photometer CE318-T, are available in some stations. The GRASP scheme based on AOD measurements alone was applied by Torres et al. (2017), showing the ability of GRASP to retrieve totalcolumn aerosol properties at night-time using this configuration. The present work attempts to go further and provide vertically resolved aerosol properties at night-time by combin- 
ing elastic lidar and the night-time AOD at 440, 675, 870 and $1020 \mathrm{~nm}$ from lunar photometry measurements.

The second night-time scheme ( $N_{1}$ scheme) approach considers that the aerosol load in the vertical column can be monitored by lunar photometry and hence changes in extensive properties can be detected, but it assumes that there are no changes in the aerosol column-integrated intensive properties; therefore, this approach considers that there are no changes in the aerosol type. The $N_{1}$ scheme proposed in this work combines elastic lidar at 355, 532 and $1604 \mathrm{~nm}$ and the night-time AOD at 440, 675, 870 and $1020 \mathrm{~nm}$. As in Torres et al. (2017), the CRI and the spherical particle fraction are assumed to be known and the values used are the averaged GRASP values retrieved during the closest (after or before) daytime retrievals. It should be noted that the $N_{1}$ scheme fixes intensive properties, but this scheme is not exactly the same procedure used in the LIRIC algorithm that uses the lidar data and column-integrated aerosol properties provided by AERONET as input. AOD at other available wavelengths have not been taken into account in order to choose only the wavelengths used in the scheme $D$ (which is used to extract CRI information at these wavelengths); in addition nighttime AOD values in the UV range are not used due to the low signal in this spectral range at night (Barreto et al., 2019).

\subsection{3 $\quad N_{2}$}

The third and last night-time scheme $\left(N_{2}\right.$ scheme) avoids any assumption of the previous schemes, assuming that intensive and extensive (as the $N_{0}$ scheme) aerosol properties do not change between day and night or using a fixed CRI and spherical particle fraction (as the $N_{1}$ scheme). As input data, the $N_{2}$ scheme uses the elastic lidar, lunar aureole normalized sky radiances at 469,533 and $608 \mathrm{~nm}$ derived by the SONA sky camera, and the night-time AOD at 440 (which is interpolated to $469 \mathrm{~nm}$ by the Ångström exponent law using 440 and $675 \mathrm{~nm}$ ), 675, 870 and $1020 \mathrm{~nm}$. This scheme needs the elastic lidar, lunar photometer and sky camera measurements, but it has the advantage that it is not dependent on daytime measurements and can retrieve extensive and intensive aerosol properties and hence is useful to detect changes in aerosol load or type throughout the night.

\section{Results}

\subsection{Columnar aerosol properties}

For studying the coherence of daytime columnar-integrated aerosol properties retrieved by GRASP (using the $D$ scheme), such retrievals are compared with those provided by the AERONET operational algorithm. Generally, the retrievals of Level 2.0 from AERONET Version 2 are used for this comparison, but for specific cases (i.e. $\mathrm{AOD}_{440}<0.4$ ) the SSA and CRI values of Level 1.5 are used instead (Holben et al., 2006). For evaluating columnar aerosol properties retrieved by GRASP at night-time, we evaluate the smoothness and temporal coherence of the variation in the aerosol retrievals throughout the night, having as benchmarks the daytime retrievals of both AERONET and the GRASP $D$ scheme.

The $P_{1}$ and $P_{2}$ periods present a situation with an apparent smooth variation in the aerosol load but with the remnants of some intensive properties, identifying the type of aerosol, throughout the whole period studied (see Fig. 2). In this sense, the selected cases offer an appropriate situation for testing the proposed schemes for night-time aerosol retrievals, having in mind the smoothness of the aerosol evolution in spite of the ample change in the aerosol load. Hereafter, evaluations of aerosol parameters retrieved by GRASP using a different input data set (different schemes) are presented.

\subsection{Columnar particle size distribution parameters}

The columnar particle size distribution can be approximated as bimodal log-normals instead of binned size distributions. The bimodal log-normals can be described using six parameters: volume concentration $\left(\mathrm{VC}_{\mathrm{i}}, \mu \mathrm{m}^{3} \mu \mathrm{m}^{-2}\right)$, volume median radius $\left(r_{v_{i}}, \mu \mathrm{m}\right)$ and standard deviation $\left(\sigma_{v_{i}}\right)$ for the fine and coarse mode. Table 2 shows the average values ( \pm standard deviation), for all available retrievals, of the size distribution parameters retrieved by GRASP using different configuration schemes and those provided by AERONET. Figure 4 shows the aerosol size distributions calculated from the parameters given in Table 2. Due to the drastic change in aerosol load (as indicated by AOD) between $P_{1}$ and $P_{2}$ periods, the results of GRASP and AERONET retrievals are provided separately for these two periods.

The aerosol size distribution parameters obtained using scheme $D$ are consistent with AERONET products, with mean relative differences between GRASP and AERONET of around $8 \%(26 \%), 12 \%(35 \%)$ and $8 \%(10 \%)$ for $\mathrm{VC}_{\mathrm{c}}$ $\left(\mathrm{VC}_{\mathrm{f}}\right)$ and $r_{v_{\mathrm{c}}}\left(r_{v_{\mathrm{f}}}\right)$ and $\sigma_{v_{\mathrm{c}}}\left(\sigma_{v_{\mathrm{f}}}\right)$ with the agreement being better for the coarse mode. In general, the coarse-mode parameters obtained during the Saharan dust event analysed here are the typical values obtained at Granada during dust events originating from the western Sahara (Valenzuela et al., 2012). It is noted that the coarse-modal radius retrieved by the GRASP $D$ scheme is slightly larger than that provided by AERONET during both periods. This shift towards larger radii for GRASP retrievals was also observed by Lopatin et al. (2013) during dust and biomass burning events over Minsk (Belarus) and by Bovchaliuk et al. (2016) during dust events over Dakar (Senegal), and it is attributed to the use of additional lidar data.

Columnar aerosol size distribution parameters at nighttime retrieved by GRASP using different schemes (see Table 2) show a good coherence and smooth variation when they are compared to daytime AERONET and GRASP retrievals (scheme $D$ ). In fact, the GRASP night-time retrievals 

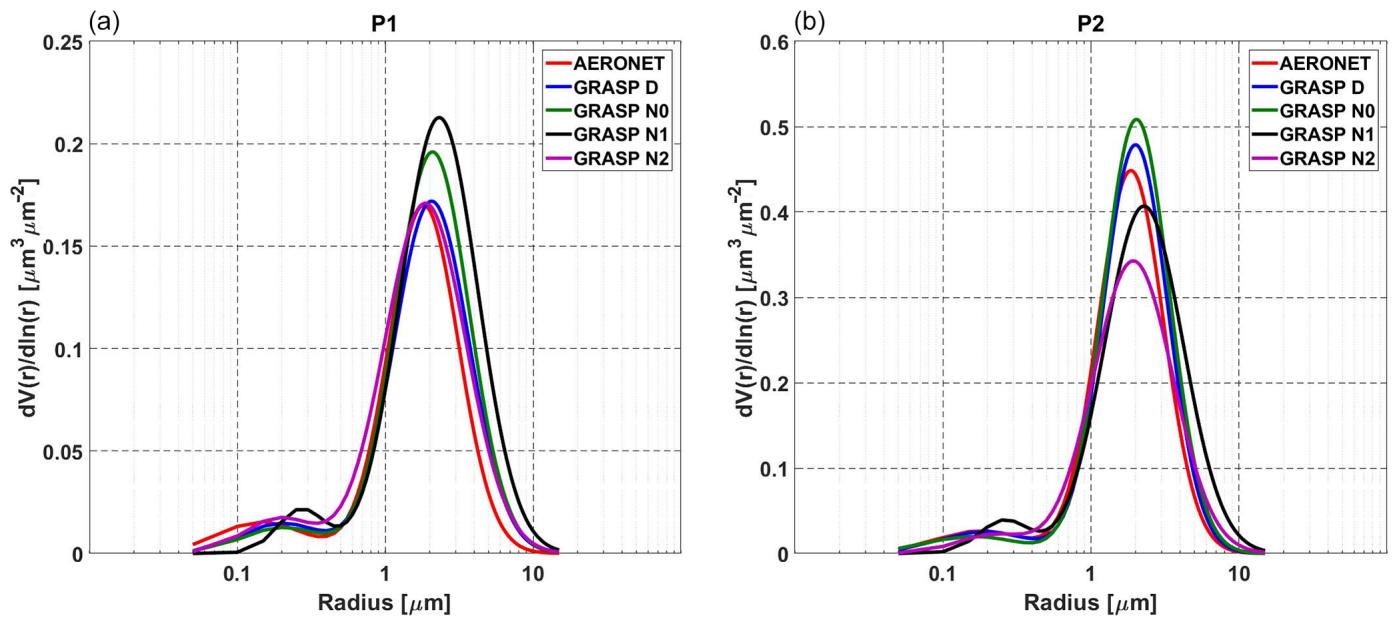

Figure 4. The aerosol size distribution calculated from the averaged aerosol size distribution parameters obtained from AERONET and GRASP retrievals both during the day and at night-time for the first period (a) and the second period (b) of dust event.

Table 2. The average values ( \pm standard deviations) of volume concentration $\left(\mathrm{VC}_{\mathrm{f}}, \mathrm{VC}_{\mathrm{c}}\right.$ as $\left.\mu \mathrm{m}^{3} \mu \mathrm{m}^{-2}\right)$, volume modal radius $\left(r_{v_{\mathrm{f}}}, r_{v_{\mathrm{c}}}\right.$ as $\mu \mathrm{m})$ and standard deviation $\left(\sigma_{v_{f}}\right.$ and $\left.\sigma_{v_{\mathrm{c}}}\right)$ for fine and coarse modes retrieved by GRASP using different configuration schemes and those provided by AERONET. The retrievals are provided for the first period $\left(P_{1}\right)$ and the second period $\left(P_{2}\right)$. The subscript " $\mathrm{f}$ " denotes the fine mode and "c" denotes the coarse mode.

\begin{tabular}{lrrrrr}
\hline & AERONET & $D$ & $N_{0}$ & $N_{1}$ & $N_{2}$ \\
\hline$P_{1}$ & & & & \\
\hline $\mathrm{VC}_{\mathrm{f}}$ & $0.026 \pm 0.007$ & $0.023 \pm 0.009$ & $0.020 \pm 0.002$ & $0.020 \pm 0.003$ & $0.024 \pm 0.002$ \\
$r_{v_{\mathrm{f}}}$ & $0.146 \pm 0.017$ & $0.20 \pm 0.03$ & $0.202 \pm 0.013$ & $0.27 \pm 0.04$ & $0.193 \pm 0.007$ \\
$\sigma_{v_{\mathrm{f}}}$ & $0.67 \pm 0.03$ & $0.62 \pm 0.06$ & $0.63 \pm 0.03$ & $0.37 \pm 0.10$ & $20.55 \pm 0.019$ \\
$\mathrm{VC}_{\mathrm{c}}$ & $0.23 \pm 0.04$ & $0.25 \pm 0.05$ & $0.28 \pm 0.05$ & $0.32 \pm 0.02$ & $0.27 \pm 0.03$ \\
$r_{v_{\mathrm{c}}}$ & $1.82 \pm 0.08$ & $2.06 \pm 0.10$ & $2.09 \pm 0.18$ & $2.32 \pm 0.03$ & $1.87 \pm 0.14$ \\
$\sigma_{v_{\mathrm{c}}}$ & $0.540 \pm 0.018$ & $0.58 \pm 0.03$ & $0.57 \pm 0.02$ & $0.60 \pm 0.03$ & $0.63 \pm 0.03$ \\
\hline$P_{2}$ & & & & & \\
\hline $\mathrm{VC}_{\mathrm{f}}$ & $0.046 \pm 0.013$ & $0.045 \pm 0.014$ & $0.037 \pm 0.005$ & $0.038 \pm 0.002$ & $0.031 \pm 0.006$ \\
$r_{v_{\mathrm{f}}}$ & $0.18 \pm 0.04$ & $0.19 \pm 0.04$ & $0.16 \pm 0.02$ & $0.26 \pm 0.08$ & $0.220 \pm 0.009$ \\
$\sigma_{v_{\mathrm{f}}}$ & $0.69 \pm 0.06$ & $0.70 \pm 0.10$ & $0.74 \pm 0.07$ & $0.39 \pm 0.13$ & $0.56 \pm 0.04$ \\
$\mathrm{VC}_{\mathrm{c}}$ & $0.57 \pm 0.07$ & $0.60 \pm 0.06$ & $0.65 \pm 0.04$ & $0.62 \pm 0.09$ & $0.53 \pm 0.04$ \\
$r_{v_{\mathrm{c}}}$ & $1.86 \pm 0.09$ & $2.00 \pm 0.09$ & $2.03 \pm 0.04$ & $2.28 \pm 0.02$ & $1.93 \pm 0.13$ \\
$\sigma_{v_{\mathrm{c}}}$ & $0.507 \pm 0.013$ & $0.50 \pm 0.04$ & $0.51 \pm 0.02$ & $0.608 \pm 0.008$ & $0.617 \pm 0.011$ \\
\hline
\end{tabular}

using the $N_{0}$ scheme present average values similar to those provided by GRASP daytime retrievals, with discrepancies around $10 \%$ for both modes in the two periods analysed. The aerosol size distribution parameters of the coarse mode retrieved by GRASP using the $N_{1}$ scheme are slightly higher systematically than those obtained during the daytime (by both the $D$ scheme and AERONET) with differences of around $15 \%$ and $10 \%$ for $\mathrm{VC}_{\mathrm{c}}$ and $r_{v_{\mathrm{c}}}$, respectively. These differences are within the uncertainties observed by Torres et al. (2017) in the cases in which the coarse mode is predominant. The use of night-time AOD measurements in the $N_{1}$ scheme, which reveals a change in AOD values (aerosol load) between day and night, may also be behind these changes in the aerosol size distribution parameters retrieved by the $N_{1}$ scheme.

Finally, the values of aerosol parameters retrieved by GRASP using the $N_{2}$ scheme are closely similar to the values retrieved by AERONET the day before and after, especially for the coarse mode where the discrepancies are around $12 \%$, $3 \%$ and $20 \%$ for $\mathrm{VC}_{\mathrm{c}}, r_{v_{\mathrm{c}}}$ and $\sigma_{v_{\mathrm{c}}}$, respectively, showing the potential of such retrievals. However, for fine-mode properties $\left(\mathrm{VC}_{\mathrm{f}}, r_{v_{\mathrm{f}}}\right.$ and $\left.\sigma_{v_{\mathrm{f}}}\right)$ there are considerable differences between GRASP and AERONET retrievals mainly due to the low concentration of fine particles. 
Table 3. The average values ( \pm standard deviation) of the real (RRI) and imaginary (IRI) refractive indices retrieved by GRASP $\left(D, N_{0}\right.$ and $N_{2}$; both fine and coarse modes) and AERONET (for the whole aerosol population) during 18-21 July 2016.

\begin{tabular}{|c|c|c|c|c|c|c|c|}
\hline \multirow[b]{3}{*}{$\lambda(\mathrm{nm})$} & \multicolumn{6}{|c|}{ GRASP } & \multirow[b]{3}{*}{ AERONET } \\
\hline & \multicolumn{3}{|c|}{ Fine } & \multicolumn{3}{|c|}{ Coarse } & \\
\hline & $D$ & $N_{0}$ & $N_{2}$ & $D$ & $N_{0}$ & $N_{2}$ & \\
\hline \multicolumn{8}{|l|}{ RRI } \\
\hline 355 & $1.44 \pm 0.02$ & $1.47 \pm 0.03$ & $1.46 \pm 0.01$ & $1.45 \pm 0.03$ & $1.43 \pm 0.03$ & $1.43 \pm 0.01$ & \\
\hline 440 & $1.44 \pm 0.02$ & $1.47 \pm 0.03$ & $1.46 \pm 0.01$ & $1.45 \pm 0.03$ & $1.43 \pm 0.03$ & $1.43 \pm 0.01$ & $1.46 \pm 0.03$ \\
\hline 532 & $1.44 \pm 0.02$ & $1.47 \pm 0.03$ & $1.46 \pm 0.01$ & $1.45 \pm 0.03$ & $1.43 \pm 0.03$ & $1.43 \pm 0.01$ & \\
\hline 675 & $1.44 \pm 0.02$ & $1.47 \pm 0.03$ & $1.47 \pm 0.01$ & $1.45 \pm 0.03$ & $1.44 \pm 0.03$ & $1.42 \pm 0.01$ & $1.47 \pm 0.03$ \\
\hline 870 & $1.45 \pm 0.02$ & $1.48 \pm 0.03$ & $1.45 \pm 0.01$ & $1.45 \pm 0.03$ & $1.43 \pm 0.03$ & $1.41 \pm 0.01$ & $1.47 \pm 0.03$ \\
\hline 1020 & $1.44 \pm 0.02$ & $1.47 \pm 0.03$ & $1.45 \pm 0.01$ & $1.45 \pm 0.03$ & $1.43 \pm 0.03$ & $1.41 \pm 0.01$ & $1.45 \pm 0.03$ \\
\hline 1064 & $1.44 \pm 0.02$ & $1.47 \pm 0.03$ & $1.45 \pm 0.01$ & $1.45 \pm 0.03$ & $1.43 \pm 0.03$ & $1.41 \pm 0.01$ & \\
\hline \multicolumn{8}{|c|}{ IRI $\left(\times 10^{-3}\right)$} \\
\hline 355 & $2.8 \pm 0.4$ & $3.2 \pm 0.2$ & $3.1 \pm 0.1$ & $10 \pm 4$ & $8 \pm 5$ & $12 \pm 6$ & \\
\hline 440 & $2.8 \pm 0.4$ & $3.2 \pm 0.2$ & $3.1 \pm 0.1$ & $5.5 \pm 2.0$ & $5.0 \pm 2.0$ & $9 \pm 3$ & $5.2 \pm 1.4$ \\
\hline 532 & $2.8 \pm 0.4$ & $3.2 \pm 0.2$ & $3.1 \pm 0.1$ & $3.4 \pm 1.1$ & $3.5 \pm 1.1$ & $6.1 \pm 1.6$ & \\
\hline 675 & $2.8 \pm 0.4$ & $3.2 \pm 0.2$ & $3.1 \pm 0.1$ & $2.0 \pm 0.6$ & $2.2 \pm 0.5$ & $3.4 \pm 0.8$ & $1.5 \pm 0.5$ \\
\hline 870 & $2.8 \pm 0.4$ & $3.2 \pm 0.2$ & $3.1 \pm 0.1$ & $1.2 \pm 0.4$ & $1.5 \pm 0.4$ & $2.5 \pm 0.7$ & $1.2 \pm 0.4$ \\
\hline 1020 & $2.8 \pm 0.4$ & $3.2 \pm 0.2$ & $3.1 \pm 0.1$ & $0.9 \pm 0.4$ & $1.2 \pm 0.4$ & $2.2 \pm 0.4$ & $1.2 \pm 0.4$ \\
\hline 1064 & $2.8 \pm 0.4$ & $3.2 \pm 0.2$ & $3.1 \pm 0.1$ & $0.8 \pm 0.3$ & $1.2 \pm 0.4$ & $2.1 \pm 0.4$ & \\
\hline
\end{tabular}

\subsubsection{Columnar complex refractive indices}

The real (RRI) and imaginary (IRI) refractive indices obtained by GRASP and AERONET are not directly comparable because the GRASP configurations used here provide the RRI and the IRI separately for fine and coarse modes while AERONET provides only RRI and IRI equivalent values for the whole size distribution. Nevertheless, the RRI and IRI values provided by AERONET are again used to study the consistency of the proposed schemes for GRASP retrievals. In this case, the mean RRI and IRI values (see Table 3) and their corresponding standard deviations correspond to the whole period analysed. This is done because, in contrast to VC retrievals that showed a large change between $P_{1}$ and $P_{2}$ periods, the RRI and the IRI retrieved by GRASP (using different schemes) and AERONET were almost stable and showed a very small variation throughout the whole period analysed, as indicated by the corresponding standard deviations. As can be seen in this table, standard deviations were within and even below the uncertainties associated with the AERONET retrievals, i.e. \pm 0.03 for the RRI and $\pm 50 \%$ for the IRI (Dubovik et al., 2000). On the other hand, it is important to remember that complex refractive index values for the $N_{1}$ scheme are not reported in Table 3 because in this case the average day values retrieved by GRASP during the daytime were used as input for this GRASP configuration scheme.

RRI values retrieved by both GRASP (using different schemes) and AERONET show no remarkable spec- tral dependence, with maximum spectral variations of 0.03 , which is below the uncertainties of the AERONET method. The differences between GRASP ( $D$ and $N_{0}$ scheme) and AERONET are similar to those obtained in previous work such as Benavent-Oltra et al. (2017) and Tsekeri et al. (2017). Also, no notable differences are observed between the retrieved values (using different GRASP schemes) between the day and night retrievals. Such coherence again shows the potential of the GRASP retrieval proposed. Moreover, retrieved RRI values agree with those reported in previous studies: using AERONET data, Dubovik et al. (2002) reported a mean RRI value of $1.48 \pm 0.05$ for desert dust at Cabo Verde. Also, using the GRASP algorithm, Tsekeri et al. (2017) obtained an RRI value of 1.45 for a desert dust event at Finokalia (Crete, Greece). Nevertheless, the RRI values obtained here are lower than those used for desert dust by several models $(\mathrm{RRI}=1.53$ for the visible spectral region) (Shettle and Fenn, 1979; WMO, 1983; Koepke et al., 1997). However, the differences between RRI values obtained here for the desert dust event and those reported in the literature can be explained by the differences in the chemical composition of dust (e.g. Patterson et al., 1977; Carlson and Benjamin, 1980; Sokolik et al., 1993; Sokolik and Toon, 1999).

For the IRI, consistency during the whole period analysed is observed again with smooth variations in the retrieved values. For the fine mode, IRI values retrieved by GRASP (using different schemes) show neutral spectral dependence, and the differences between the three schemes $\left(D, N_{0}\right.$ and $\left.N_{2}\right)$ are very small, with mean difference values of around 0.003 . But 
Table 4. The average values ( \pm standard deviation) of single-scattering albedo (SSA) retrieved by GRASP (using $D, N_{0}$ and $N_{2}$ schemes) and AERONET for the period 18-21 July 2016 (* $469 \mathrm{~nm}$ for the $N_{2}$ scheme).

\begin{tabular}{lccccc}
\hline & \multicolumn{5}{c}{ SSA } \\
\cline { 2 - 5 }$\lambda(\mathrm{nm})$ & $D$ & $N_{0}$ & $N_{1}$ & $N_{2}$ & \multirow{2}{*}{ AERONET } \\
\cline { 2 - 5 } & \multicolumn{5}{c}{ GRASP } \\
\hline 355 & $0.85 \pm 0.02$ & $0.85 \pm 0.03$ & $0.83 \pm 0.02$ & $0.82 \pm 0.05$ & \\
$440^{*}$ & $0.89 \pm 0.02$ & $0.88 \pm 0.02$ & $0.88 \pm 0.02$ & $0.86 \pm 0.03$ & $0.89 \pm 0.03$ \\
532 & $0.93 \pm 0.01$ & $0.92 \pm 0.02$ & $0.92 \pm 0.01$ & $0.89 \pm 0.02$ & \\
675 & $0.96 \pm 0.01$ & $0.95 \pm 0.01$ & $0.96 \pm 0.01$ & $0.94 \pm 0.01$ & $0.97 \pm 0.03$ \\
870 & $0.98 \pm 0.01$ & $0.97 \pm 0.01$ & $0.98 \pm 0.01$ & $0.96 \pm 0.01$ & $0.98 \pm 0.03$ \\
1020 & $0.98 \pm 0.01$ & $0.98 \pm 0.01$ & $0.98 \pm 0.01$ & $0.97 \pm 0.01$ & $0.98 \pm 0.03$ \\
1064 & $0.99 \pm 0.01$ & $0.98 \pm 0.01$ & $0.98 \pm 0.01$ & $0.97 \pm 0.01$ & \\
\hline
\end{tabular}

for the coarse mode a spectral behaviour of the IRI retrieved by GRASP is observed with similar values to the AERONET retrievals. The observed spectral dependence in the IRI is that typically observed for desert dust with a higher IRI in the UV region (Patterson et al., 1977; Dubovik et al., 2002; Wagner et al., 2012). The mean IRI values retrieved using $D$ and $N_{0}$ schemes for the coarse mode are almost similar to AERONET retrievals, the differences being within the uncertainties (about $50 \%$ ) associated with the IRI provided by AERONET (Dubovik et al., 2000) and similar to those obtained in previous work such as Benavent-Oltra et al. (2017) and Tsekeri et al. (2017). Although the discrepancy between IRI values retrieved using the $N_{2}$ scheme for the coarse mode and those provided by AERONET is high, the IRI values of the $N_{2}$ scheme are consistent with IRI values of around 0.008 at $675 \mathrm{~nm}$ obtained at night-time during a dust event in Dakar (Senegal) by Bovchaliuk et al. (2016). Considering the success in this issue for daytime IRI retrievals, it can be concluded that accurate AOD and sky measurements combined with lidar measurements are useful for accurately characterizing CRI and particularly for separating the features of fine and coarse modes as discussed by Dubovik et al. (2000). The approach proposed using additional relative radiance in the lunar aureole is also promising for the retrievals of CRI values. Nevertheless, further studies on the IRI retrieved using night-time sky cameras are required.

\subsubsection{Columnar single-scattering albedo}

Table 4 shows the averaged values of SSA and their corresponding standard deviations obtained by GRASP (using different schemes) and AERONET during the whole dust event. As for IRI and RRI retrievals, SSA values retrieved by both GRASP and AERONET show very small temporal variation during the whole period analysed, as confirmed by the low standard deviations of the SSA values.

SSA retrieved by GRASP and AERONET shows a smooth variability between day and night for the total period. Actually, mean differences in SSA values retrieved by GRASP and AERONET are below 0.03, which it is within the uncertainty associated with AERONET retrieval for dust aerosol (Dubovik et al., 2000) and similar to those obtained in previous work, such as Benavent-Oltra et al. (2017) and Tsekeri et al. (2017), for all the proposed schemes. Moreover, SSA values retrieved by both GRASP and AERONET present a common and remarkable spectral variability with SSA increasing from values of around 0.85 in the UV region to values of around 0.99 in the near-infrared. Such SSA values and spectral dependence with wavelength is typically found in pure desert dust (Dubovik et al., 2002; Valenzuela et al., 2012). These results are in agreement with the observed for the IRI, likely indicating that all proposed schemes can extract some information about aerosol absorption from the measurements used as input and/or from the self-retrieval strategy in the case of $N_{1}$.

\subsection{Evaluation of vertical aerosol properties}

\subsubsection{Aerosol extinction profiles at night-time}

The multiwavelength lidar system used in this work has two channels detecting Raman scattering at 387 and $607 \mathrm{~nm}$; the Raman method is applied here to independently obtain the aerosol extinction coefficient at 355 and $532 \mathrm{~nm}$. The aerosol extinction profile at $1064 \mathrm{~nm}$ is computed using the backscatter coefficient retrieved from the Klett-Fernald method with a constant LR for the entire profile of $50 \mathrm{sr}$, which is a representative value of desert dust (Guerrero-Rascado et al., 2009). Because Raman measurements of this lidar system are noisy, the lidar signal is averaged to $\pm 15 \mathrm{~min}$ around the GRASP retrieval time to get a high signal-to-noise ratio. Raman lidar profiles are obtained with a vertical resolution of $7.5 \mathrm{~m}$, and then they are vertically smoothed. The comparison presented hereafter is made between the GRASP values and the Raman values obtained at the closest chosen 60 logspaced heights in GRASP.

Figure 5 shows the aerosol extinction profiles for the three cases where we have the three night-time scheme re- 
Table 5. Differences ( \pm standard deviation) between the extinction values retrieved by GRASP $\left(N_{0}, N_{1}\right.$ and $N_{2}$ schemes) and Raman during the dust event observed over Granada from 18 to 21 July 2016. The percentage differences are in parentheses.

\begin{tabular}{lrrr}
\hline $\begin{array}{l}\Delta \alpha(\lambda) \\
\left(\mathrm{Mm}^{-1}\right)\end{array}$ & $N_{0}$ & $N_{1}$ & $N_{2}$ \\
\hline $355 \mathrm{~nm}$ & $1.3 \pm 40(23 \%)$ & $-11 \pm 31(23 \%)$ & $-20 \pm 30(24 \%)$ \\
$532 \mathrm{~nm}$ & $-30 \pm 30(30 \%)$ & $-30 \pm 30(30 \%)$ & $-40 \pm 40(40 \%)$ \\
$1064 \mathrm{~nm}$ & $15 \pm 24(21 \%)$ & $20 \pm 23(24 \%)$ & $12 \pm 22(20 \%)$ \\
\hline
\end{tabular}

trievals by GRASP and Raman at 355, 532 and $1064 \mathrm{~nm}$. In general, GRASP profiles show similar behaviour to Raman with a slight shift that could be caused by smoothing applied to Raman profiles. The extinction profiles retrieved by GRASP are within the uncertainties of the Raman technique (around 20\%) with the exception of the second case (Fig. 5b), where the $N_{2}$ scheme shows large differences with Raman at 355 and $532 \mathrm{~nm}$. For this case, the $N_{2}$ GRASP retrieval fits Raman worse than the other schemes, likely since the obtained residual error was higher than the residuals of $N_{0}$ and $N_{1}$ retrievals which presented higher convergence.

In order to quantify the agreement between the retrieved extinction with GRASP and Raman, Fig. 6 shows aerosol extinction coefficients at 355,532 and $1064 \mathrm{~nm}$ retrieved by GRASP $\left(N_{0}, N_{1}\right.$ and $N_{2}$ schemes) at night-time versus the values obtained by multiwavelength Raman lidar measurements during the dust event observed over Granada in the period 18-21 July 2016. For all schemes and all wavelengths, $\alpha$ retrieved by GRASP and those obtained by Raman lidar measurements are highly correlated with a determination coefficient $\left(r^{2}\right)$ ranging from 0.8 to 0.9 . The slopes of the regression lines varied between 0.75 and 1.07 , indicating that in general the proposed GRASP schemes underestimate the aerosol extinction coefficient obtained by the Raman and Klett-Fernald methods. A statistical overview of the differences between $\alpha$ from GRASP retrievals and from Raman measurements is given in Table 5. Particularly, the mean and standard deviation of the differences are given by $\Delta \alpha=$ $\alpha_{\text {GRASP }}-\alpha_{\text {Raman }}$, and the average of the relative absolute differences given by $\Delta \alpha(\%)=100 \cdot\left|\alpha_{\mathrm{GRASP}}-\alpha_{\text {Raman }}\right| / \alpha_{\text {Raman }}$ are also shown.

The relative differences at $355 \mathrm{~nm}$ between $\alpha$ values retrieved by GRASP and those obtained from Raman lidar measurements are around $23 \%$ for the three schemes. The lowest bias at $355 \mathrm{~nm}$ between values retrieved by GRASP and those obtained from Raman lidar measurements is found for the $N_{0}$ scheme $\left(1.3 \pm 40 \mathrm{Mm}^{-1}\right)$, while the highest absolute bias $\left(20 \pm 30 \mathrm{Mm}^{-1}\right)$ is obtained for $N_{2}$ schemes. However, for $532 \mathrm{~nm}$, the differences between GRASP and Raman lidar values are larger than those encountered at 355 and $1064 \mathrm{~nm}$, being the relative differences of $30 \%, 30 \%$ and $40 \%$ for $N_{0}, N_{1}$ and $N_{2}$ schemes, respectively. In addition, the mean biases are higher in this case, being $-30 \pm 30$,
$-30 \pm 30$ and $-40 \pm 40 \mathrm{Mm}^{-1}$ for $N_{0}, N_{1}$ and $N_{2}$ schemes, respectively. Finally, for $1064 \mathrm{~nm}$, the lowest differences appear for the $N_{2}$ scheme, in contrast with the other wavelengths; the relative differences range from $20 \%$ to $24 \%$ for this wavelength. In general, the obtained GRASP aerosol extinction underestimates Raman measurements at $532 \mathrm{~nm}$ for all night-time schemes, while these schemes overestimate the aerosol extinction obtained from Raman measurements at $1064 \mathrm{~nm}$. Part of the observed differences could be associated with the assumption associated with the incomplete overlap region, where aerosol properties have been assumed as constant in all this area (Herreras et al., 2019). Also, the rather broad assumption of a constant lidar ratio used in the estimation of the extinction at $1064 \mathrm{~nm}$, derived from the backscatter coefficient retrieved by the Klett-Fernald retrieval, could explain a part of the observed discrepancies at $1064 \mathrm{~nm}$. In general, the differences between GRASP and Raman retrievals present in this work are similar to the differences obtained in previous studies (e.g. Bovchaliuk et al., 2016; Benavent-Oltra et al., 2017; Tsekeri et al., 2017).

\subsubsection{GRASP retrievals versus in situ measurements}

Hereafter, $\sigma_{\text {sca }}(\lambda)$ and VC retrieved by GRASP are compared to the in situ measurements obtained at SNS (2.5 km a.s.1.). In Fig. 7, the averaged profiles of the scattering coefficient at $532 \mathrm{~nm}$ (Fig. 7a) and volume concentration profiles (Fig. 7b) retrieved by GRASP night-time schemes are shown. The selected profiles correspond to cases where we have retrievals of all $N_{0}, N_{1}$ and $N_{2}$ schemes: three cases for $P_{1}$ and six cases for the $P_{2}$ period. In the same figure, we added the averaged in situ measurements at SNS, both scattering coefficient at $550 \mathrm{~nm}$ and volume concentration. $N_{0}$ and $N_{1}$ profiles are very similar with low differences $(<5 \%)$, while $\mathrm{N}_{2}$ profiles have lower values in comparison with these two schemes, with differences of around $15 \%$. In the case of low aerosol load ( $P_{1}$ period), GRASP $N_{0}$ and $N_{1}$ profiles are closer than in situ measurements for both $\sigma_{\text {sca }}$ and VC, while the $N_{2}$ scheme underestimates these measurements. In contrast, for the $P_{2}$ period, the three schemes show good coherence with in situ measurements, especially the VC retrieved by the GRASP $N_{2}$ scheme.

For a direct comparison between GRASP and in situ measurements, we used the averaged values of GRASP retrievals at an altitude of $2.5 \pm 0.2 \mathrm{~km}$ a.s.l. and in situ measurements averaged \pm 15 min around the GRASP retrieval time. Comparisons of $\sigma_{\text {sca }}$ are made at 450,550 and $700 \mathrm{~nm}$, and the AE computed from GRASP retrievals is used to get the equivalent $\sigma_{\text {sca }}$ at these wavelengths. Figure 8a shows the temporal evolutions of $\sigma_{\text {sca }}$ at $550 \mathrm{~nm}$ obtained by $\operatorname{GRASP}\left(D, N_{0}\right.$, $N_{1}$ and $N_{2}$ schemes) and by the integrating nephelometer at SNS for the analysed dust event. Generally, both GRASP and in situ measurements follow the same pattern and are sensitive to the arrival of Saharan dust particles. Furthermore, differences between GRASP (using different schemes) and 

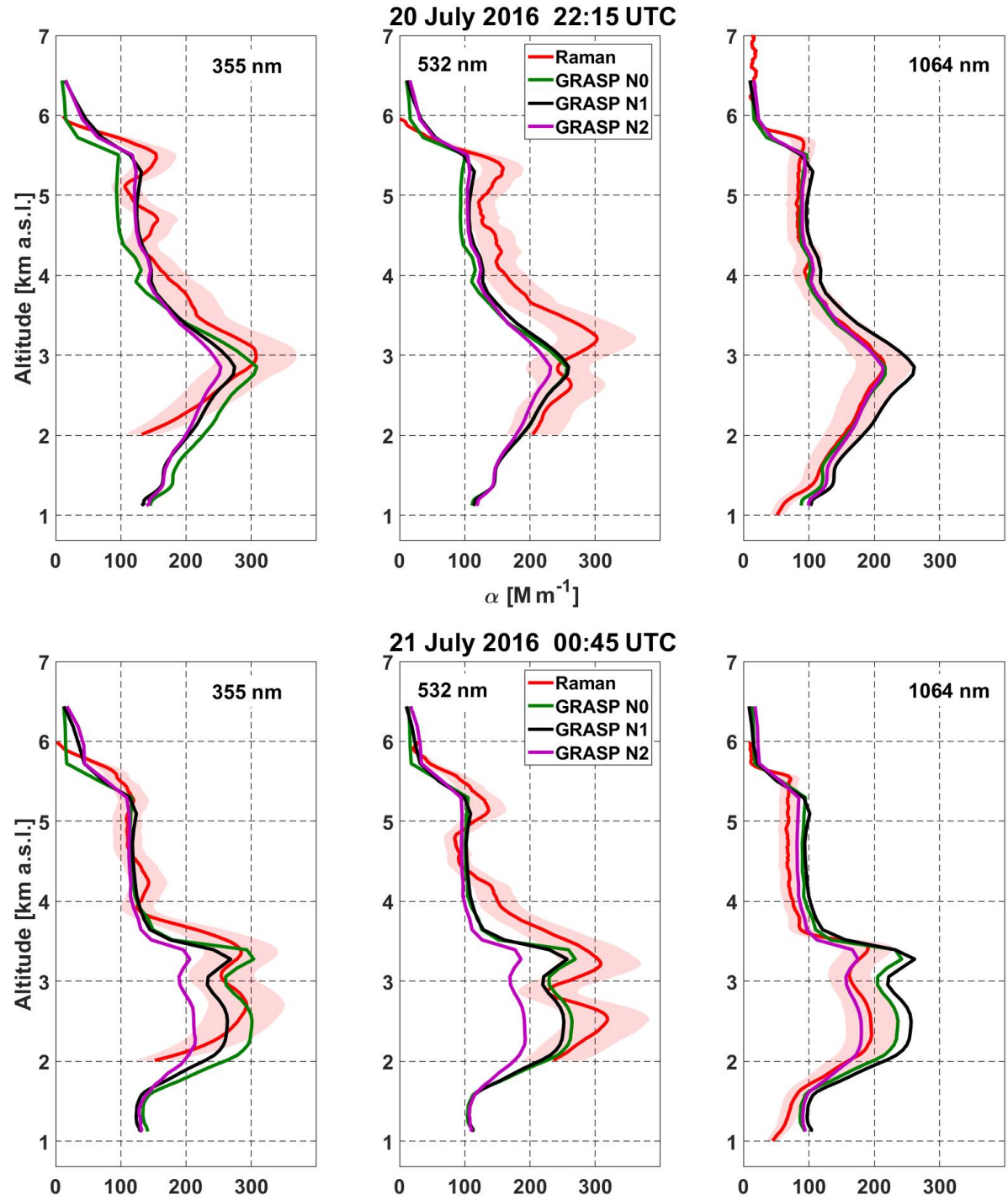

21 July 2016 00:45 UTC
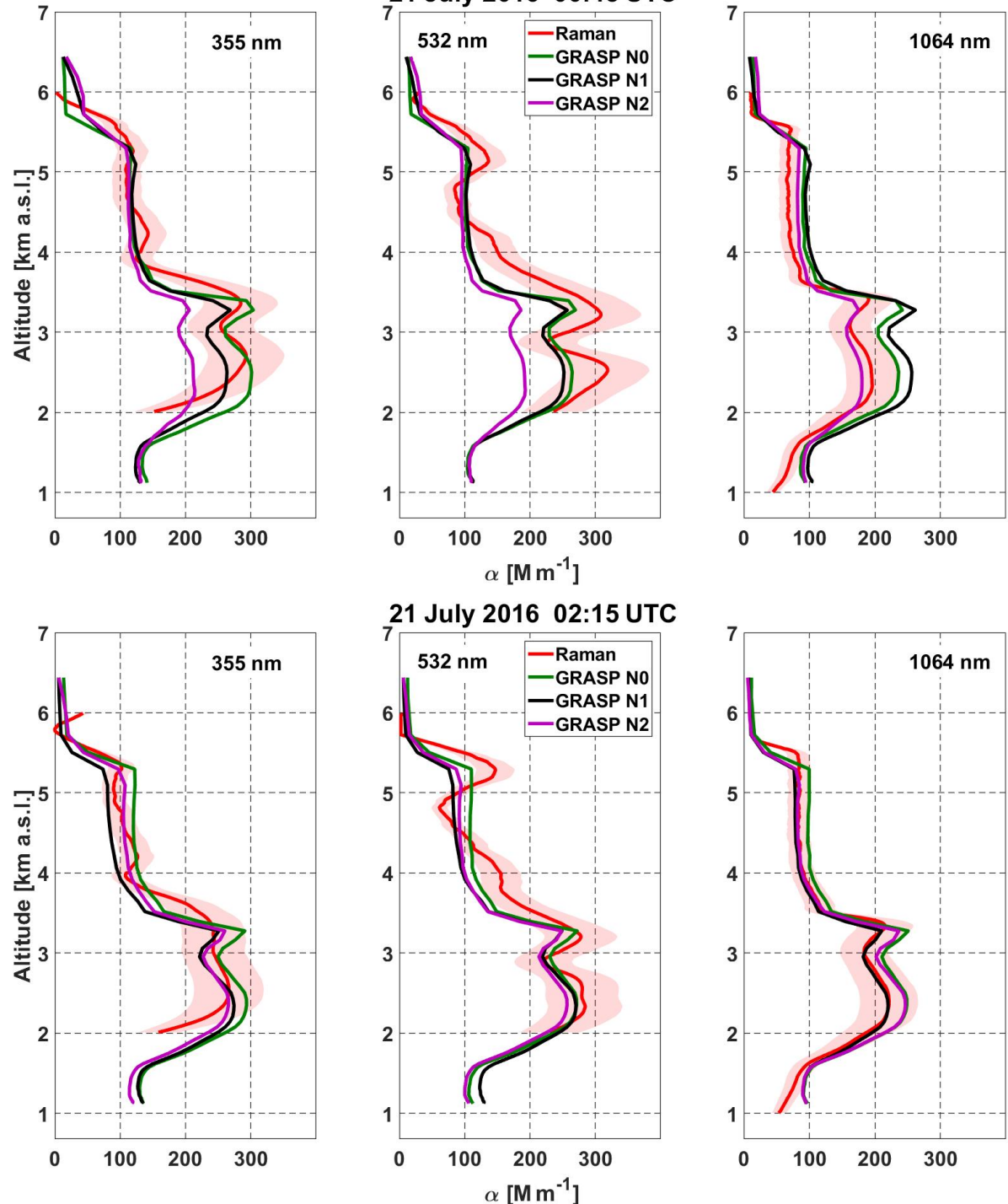

Figure 5. The aerosol extinction profiles retrieved by GRASP (for night-time schemes) and those calculated by the Raman technique at 355 and $532 \mathrm{~nm}$ and the Klett-Fernald method at $1064 \mathrm{~nm}$. 

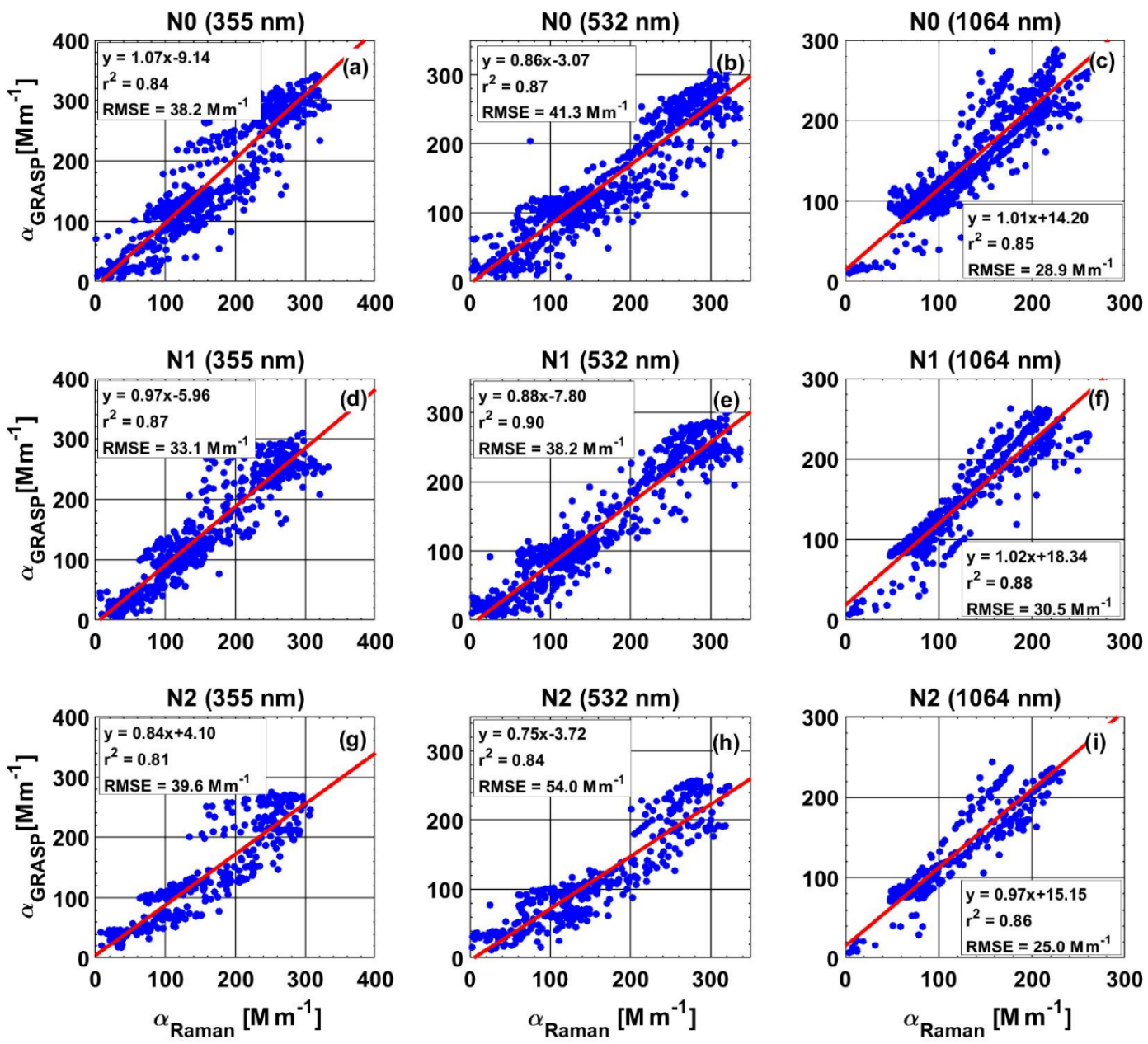

Figure 6. Aerosol extinction coefficient $(\alpha)$ retrieved by GRASP for $N_{0}(\mathbf{a}-\mathbf{c}), N_{1}(\mathbf{d}-\mathbf{f})$ and $N_{2}(\mathbf{g}-\mathbf{i})$ as a function of the $\alpha$ calculated by the Raman technique at $355(\mathbf{a}, \mathbf{d}, \mathbf{g})$ and $532 \mathrm{~nm}(\mathbf{b}, \mathbf{e}, \mathbf{h})$ and the Klett-Fernald method at $1064 \mathrm{~nm}(\mathbf{c}, \mathbf{f}, \mathbf{i})$ during the dust event observed over Granada during 18-21 July 2016.
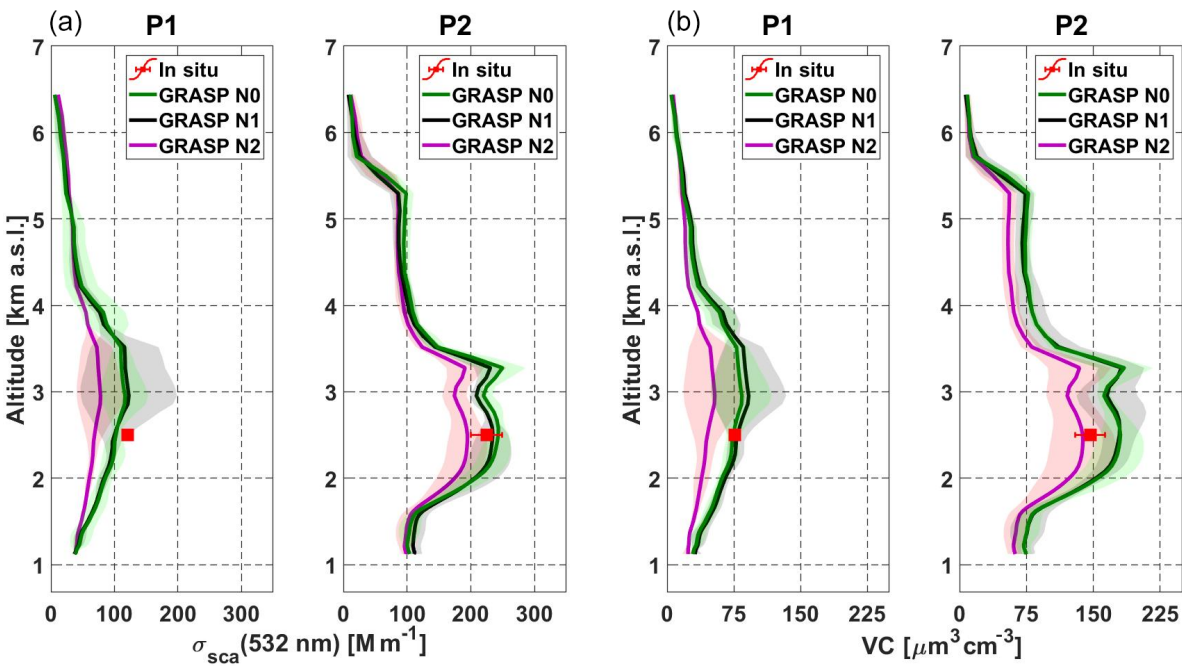

Figure 7. The averaged $\sigma_{\text {sca }}$ at $532 \mathrm{~nm}$ (a) and VC (b) profiles with its standard deviation (shaded area) retrieved by GRASP $N_{0}, N_{1}$ and $\mathrm{N}_{2}$ schemes. In red, the averaged in situ measurements obtained at $2500 \mathrm{~m}$ a.s.1. at SNS. 

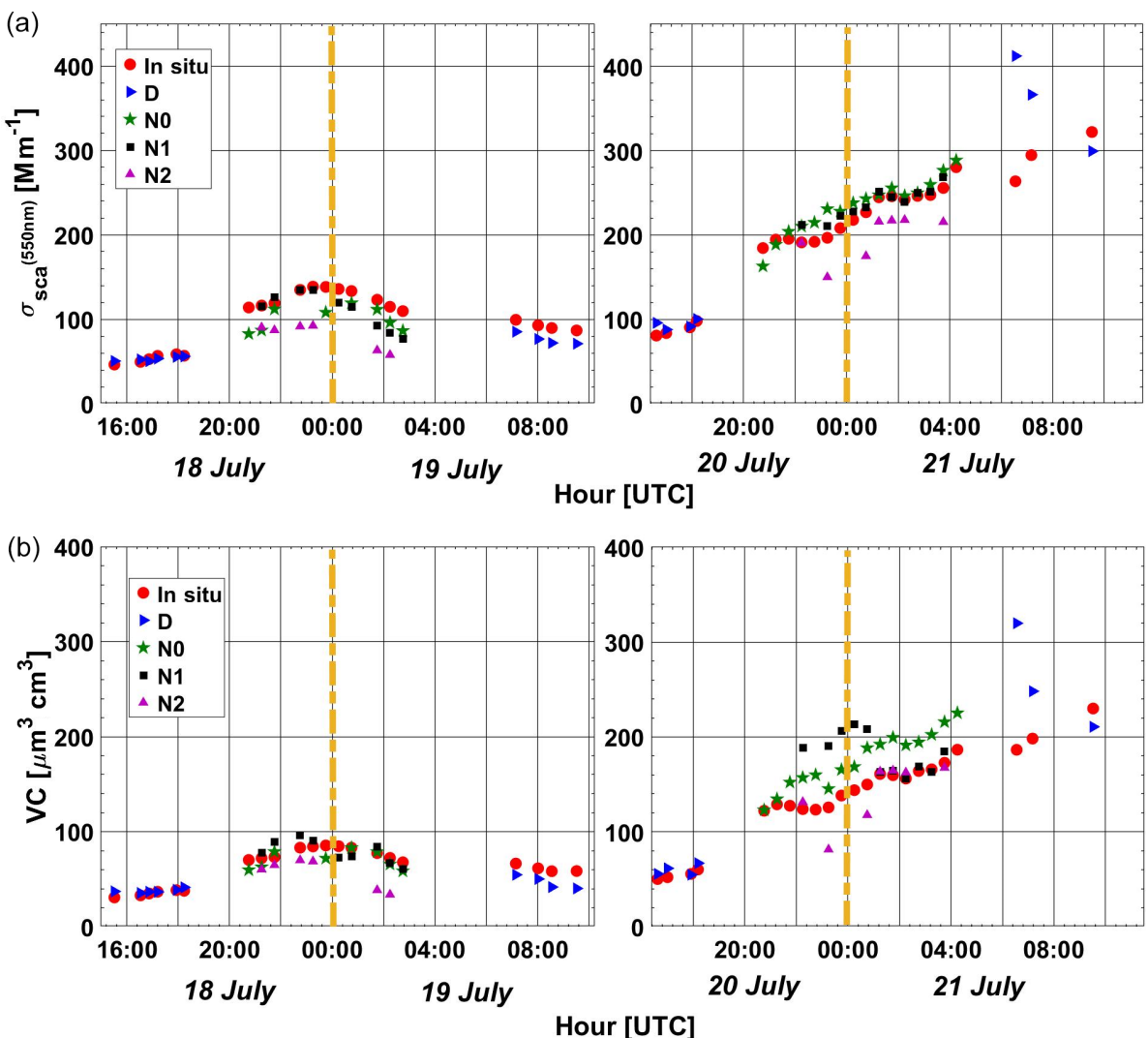

Figure 8. Temporal evolutions of $\sigma_{\mathrm{sca}}$ at $550 \mathrm{~nm}$ (a) and VC (b) measured at SNS (red) and retrieved by GRASP ( $D:$ blue; $N_{0}$ : green; $N_{1}$ : black; $N_{2}$ : purple) at $2.5 \mathrm{~km}$ a.s.l. from 18 to 21 July 2016.

in situ measurements are very small, the differences being less than $25 \mathrm{Mm}^{-1}$ in $90 \%$ of the cases. Generally, the differences are negligible for the daytime. For night-time, the best agreement is found for the $N_{1}$ scheme and the worst accordance is obtained for the $N_{2}$ scheme. The worst accordance for the $N_{2}$ scheme could be due to the smaller scattering angle range of the almucantar radiance retrieved from the Moon aureole. In addition, the number of available retrievals for each scheme can also be seen in Fig. 7; when a retrieval does not appear in the figure, it is because this retrieval did not pass the imposed convergence criteria.

Figure $9 \mathrm{a}-\mathrm{c}$ show the scattering coefficients at 450 , 550 and $700 \mathrm{~nm}$ retrieved by GRASP using the different schemes versus those measured in situ at SNS. As can be seen in these figures, the measured and the retrieved values are well correlated, showing high $r^{2}$ values between 0.87 and 0.97 , although, in general, linear fits indicate that GRASP underestimates the in situ scattering coefficient measurements for low values while showing an overestimation for high values.

An overview of the statistical analysis of the differences between GRASP retrievals and in situ scattering coefficient measurements is given in Table 6 that shows the mean of the differences expressed as $\left(\Delta \sigma_{\mathrm{sca}}=\sigma_{\mathrm{sca}}^{\mathrm{GRASP}}-\sigma_{\mathrm{sca}}^{\mathrm{SNS}}\right)$ and also the mean of the relative differences $\Delta \sigma_{\mathrm{sca}}=100 \cdot \mid \sigma_{\mathrm{sca}}^{\mathrm{GRASP}}$ $\sigma_{\text {sca }}^{\mathrm{SNS}} \mid / \sigma_{\mathrm{sca}}^{\mathrm{SNS}}$ for each scheme. Due to the drastic change in the scattering coefficient between $P_{1}$ and $P_{2}$ periods, this statistical analysis is provided separately for these two periods. For the $P_{1}$ period, the GRASP algorithm underestimates the in situ scattering coefficient measurements both during the day and at night, especially for $N_{0}$ and $N_{2}$ schemes, and at all wavelengths. The highest differences are found for the $\mathrm{N}_{2}$ scheme with differences between $30 \%$ (at $700 \mathrm{~nm}$ ) and $35 \%$ (at $550 \mathrm{~nm})$. However, for the other schemes $\left(D, N_{0}\right.$ and $N_{1}$ ) the differences are less than $20 \%$. Again, the uncertainties associated with the IRI and with the incomplete overlap assumption as well as the particle loss in the sampling inlet may be behind these differences. However, for the $P_{2}$ period, the differences are considerably small, and in some cases they even go down to half of the differences observed in the $P_{1}$ period. By contrast with $P_{1}$, GRASP overestimates the in situ scattering coefficient in $P_{2}$ for all schemes except for $N_{2} . N_{1}$, followed by $N_{0}$, presents the scattering values fitting the in situ measurements best during the $P_{2}$ period, while the $D$ scheme shows the highest differences. The uncertainties associated with the IRI and with the incomplete overlap assumption as well as the particle loss in the sampling inlet and uncertainties in the measurements (used as 

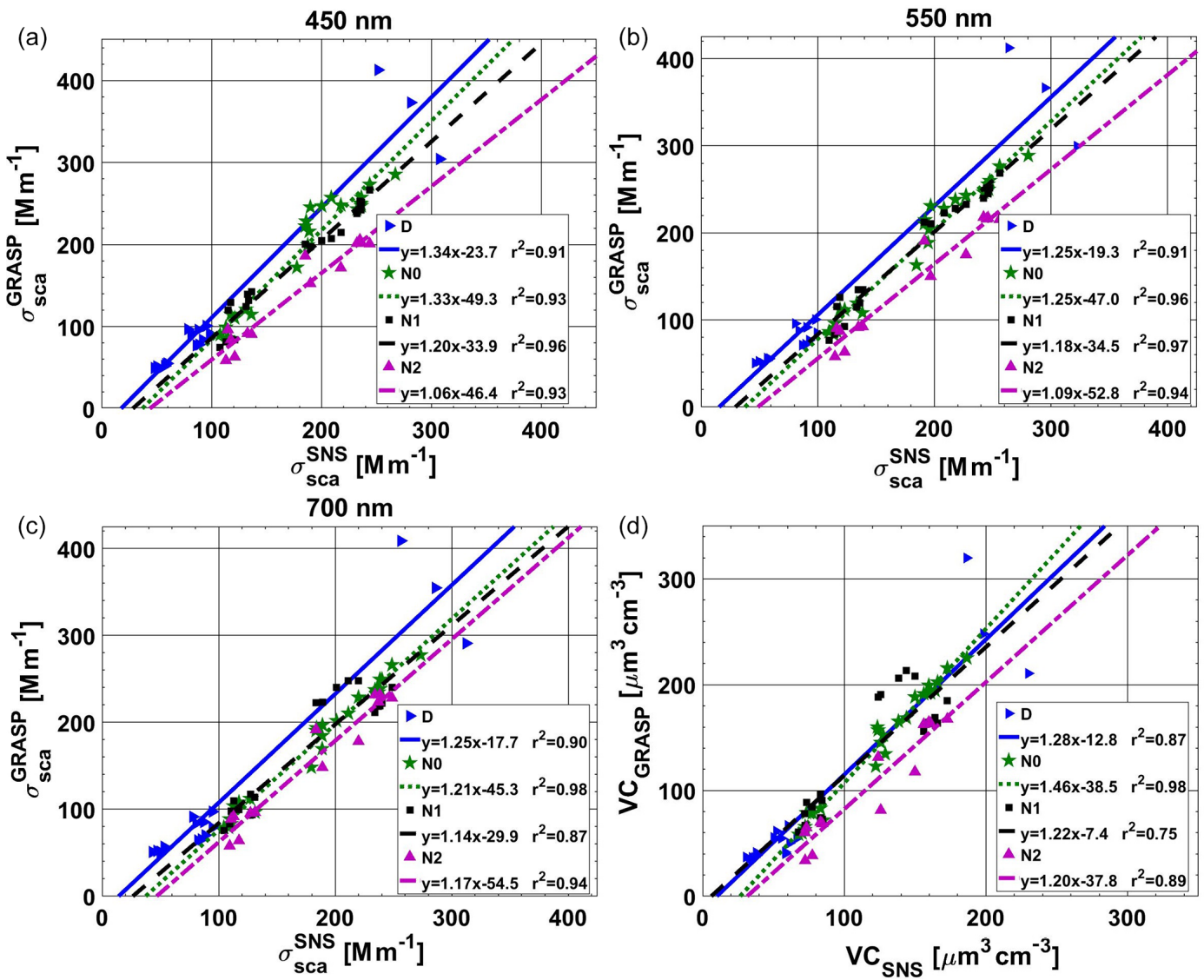

Figure 9. Scattering coefficient, $\sigma_{\mathrm{sca}}$, at 450,550 and $700 \mathrm{~nm}(\mathbf{a}-\mathbf{c})$ and volume concentration (VC) (d) retrieved by GRASP (D: blue; $N_{0}$ : green; $N_{1}$ : black; $N_{2}$ : purple) at SNS height versus in situ scattering coefficient and volume concentration measurements at SNS during the dust event over Granada in the period 18-21 July 2016.

input in GRASP but also from the nephelometer) could also be behind at least part of the observed differences.

Figure $8 \mathrm{~b}$ shows the temporal evolutions of the VC retrieved by GRASP at $2500 \mathrm{~m}$ a.s.l. and those measured at SNS. As for the scattering coefficient, the VC retrieved by GRASP and that measured at SNS follow the same pattern, both being sensitive to the increase in dust event intensity. Differences during the daytime are negligible, while at nighttime the differences depend on the GRASP scheme used, the differences in the $P_{1}$ period being much smaller than in the $P_{2}$ period, indicating that the differences increase with increasing aerosol load. Figure $9 \mathrm{~d}$ shows the VC values retrieved by GRASP (using different schemes) versus those measured at SNS. The correlation between the measured and the retrieved values is very high with $r^{2}$ between 0.75 and 0.98 . As in the case of the scattering coefficient, linear fits indicate an underestimation by GRASP for low values and an overestimation for high values.

Table 7 presents an overview of the statistical analysis of $\mathrm{VC}$ comparisons. This table shows the mean of $\Delta \mathrm{VC}=\mathrm{VC}_{\mathrm{GRASP}}-\mathrm{VC}_{\mathrm{SNS}}$ and the mean of the absolute relative differences described by $\Delta \mathrm{VC}(\%)=100 \cdot \mid \mathrm{VC}_{\mathrm{GRASP}}-$
$\mathrm{VC}_{\mathrm{SNS}} \mid / \mathrm{VC}_{\mathrm{SNS}}$. It is clearly observed that GRASP fits the measured values within $15 \%$ for $D, N_{0}$ and $N_{1}$ schemes during the $P_{1}$ period, while for the $N_{2}$ scheme an underestimation of around $30 \%$ is observed. However, for the $P_{2}$ period, VC from GRASP overestimates the in situ measurements with differences of around $20 \%$ for $D, N_{0}$ and $N_{1}$ schemes; while for the $N_{2}$ scheme, GRASP still underestimates the in situ measurements again but with lower differences of around $10 \%$ than the $P_{1}$ period. The differences between GRASP (all schemes) and in situ data are within the differences obtained in previous studies that compared GRASP retrievals with in situ airborne measurements and the LIRIC algorithm (e.g. Bovchaliuk et al., 2016; Benavent-Oltra et al., 2017; Tsekeri et al., 2017). The different assumption in the GRASP algorithm and the particle loss in the sampling inlet (which increases with increasing aerosol load) may be behind the observed differences between GRASP retrievals and in situ measurements. 
Table 6. Differences ( \pm standard deviation) between the scattering values retrieved by GRASP $\left(N_{0}, N_{1}\right.$ and $N_{2}$ schemes) and in situ measurements at SNS provided for the first period $\left(P_{1}\right)$ and the second period $\left(P_{2}\right)$.

\begin{tabular}{llrrrr}
\hline $\begin{array}{l}\Delta \sigma_{\text {sca }} \\
\left(\mathrm{Mm}^{-1}\right)\end{array}$ & $\begin{array}{l}\lambda \\
(\mathrm{nm})\end{array}$ & $D$ & $N_{0}$ & $N_{1}$ & $N_{2}$ \\
\hline & 450 & $-5 \pm 4(8 \%)$ & $-17 \pm 10(14 \%)$ & $-9 \pm 19(13 \%)$ & $-40 \pm 14(30 \%)$ \\
$P_{1}$ & 550 & $-7 \pm 8(10 \%)$ & $-20 \pm 9(17 \%)$ & $-14 \pm 15(13 \%)$ & $-43 \pm 13(40 \%)$ \\
& 700 & $-5 \pm 11(12 \%)$ & $-21 \pm 9(19 \%)$ & $-21 \pm 11(17 \%)$ & $-36 \pm 14(30 \%)$ \\
\hline & 450 & $40 \pm 60(21 \%)$ & $26 \pm 17(13 \%)$ & $9 \pm 8(5 \%)$ & $-31 \pm 16(14 \%)$ \\
$P_{2}$ & 550 & $30 \pm 60(16 \%)$ & $11 \pm 13(7 \%)$ & $8 \pm 7(4 \%)$ & $-32 \pm 17(13 \%)$ \\
& 700 & $30 \pm 60(16 \%)$ & $1.3 \pm 12(4 \%)$ & $6 \pm 30(12 \%)$ & $-17 \pm 19(9 \%)$ \\
\hline
\end{tabular}

Table 7. Differences ( \pm standard deviation) between the volume concentration values retrieved by GRASP $\left(N_{0}, N_{1}\right.$ and $N_{2}$ schemes $)$ and in situ measurements at SNS provided for the first period $\left(P_{1}\right)$ and the second period $\left(P_{2}\right)$.

\begin{tabular}{lrrrr}
\hline $\begin{array}{l}\Delta \mathrm{VC} \\
\left(\mu \mathrm{m}^{3} \mathrm{~cm}^{-3}\right)\end{array}$ & $D$ & $N_{0}$ & $N_{1}$ & $N_{2}$ \\
\hline$P_{1}$ & $-4 \pm 9(14 \%)$ & $-5 \pm 7(9 \%)$ & $1.6 \pm 10(12 \%)$ & $-21 \pm 14(30 \%)$ \\
$P_{2}$ & $30 \pm 50(20 \%)$ & $29 \pm 12(20 \%)$ & $31 \pm 32(23 \%)$ & $-9 \pm 21(10 \%)$ \\
\hline
\end{tabular}

\section{Summary and conclusions}

The main goal of this work has been to explore the capacity and possibilities of the GRASP (Generalized Retrieval of Aerosol and Surface Properties) algorithm to retrieve vertical profiles and column-integrated optical and microphysical aerosol properties at night-time. To this end, we proposed three different schemes combining the measurements of different remote-sensing instruments such as elastic lidar, sunsky-lunar photometer and/or sky camera. The experimental measurements used in this wok were acquired during a Saharan dust event that took place during the Sierra Nevada Lidar aerOsol Profiling Experiment I (SLOPE I) campaign at Granada (Spain) from 18 to 21 July 2016. This event has been selected because intensive aerosol properties such as the Ångström exponent did not vary too much, with a value of around 0.2, and were very intense, with aerosol optical depth (AOD) reaching twice the typical values for Saharan dust outbreaks at Granada.

The three schemes proposed to run GRASP for night-time retrievals have different assumptions, such as the following: no day-night variation in aerosol intensive or extensive (except vertical distribution) properties ( $N_{0}$ scheme); no daynight variation in aerosol intensive properties but possible changes in extensive aerosol properties ( $N_{1}$ scheme); daynight variation in both intensive and extensive aerosol properties ( $N_{2}$ scheme).

AERONET inversion products have been used to study the coherence of GRASP night-time retrievals and of the continuous day-to-night aerosol evolution. For the parameters derived from columnar aerosol size distributions, all GRASP schemes show coherent values with AERONET. A similar thing happens for the complex refractive index (CRI) and single-scattering albedo (SSA), although more variability is observed, particularly for the $N_{2}$ scheme due likely to the large uncertainties in relative sky radiance measurements at lunar aureole and the higher freedom degrees assumed than in the $N_{1}$ scheme. Nevertheless, we were not able to go further in the evaluation of the accuracy of the GRASP retrieved parameters. Doing so would require a large synthetic database that is beyond the scope of the paper. Also, it is needed to study the sensitivity of retrievals to errors in the input optical data, which is the objective of future work.

In general, the aerosol extinction from GRASP and Raman measurements agrees quite well, with differences below $30 \%$ at 355,532 and $1064 \mathrm{~nm}$. The scattering coefficient $\left(\sigma_{\mathrm{sca}}\right)$ and aerosol volume concentration $(\mathrm{VC})$ retrieved by GRASP (using different schemes) at $2500 \mathrm{~m}$ a.s.l. have been evaluated against in situ measurements acquired at Sierra Nevada Station during a dust event classified into two periods: moderate $\left(P_{1}\right)$ and high $\left(P_{2}\right)$ aerosol load. Usually, both GRASP retrievals and in situ measurements follow the same patterns and are sensitive to the arrival of Saharan dust particles. The GRASP $N_{0}$ and $N_{1}$ schemes underestimate the in situ $\sigma_{\mathrm{sca}}$ and VC measurements for the $P_{1}$ period (except for VC from the $N_{1}$ scheme) and overestimate them for the $P_{2}$ period, with differences between $4 \%$ and $23 \%$. On the other hand, the GRASP $N_{2}$ scheme underestimates the in situ measurement both $\sigma_{\mathrm{sca}}$ and $\mathrm{VC}$, with differences of around $30 \%$ and $10 \%$ for the $P_{1}$ and $P_{2}$ periods, respectively. In general, $N_{2}$ show slightly higher differences than other schemes; however, the best results for VC in $P_{2}$ are for the $N_{2}$ scheme. 
The obtained differences could likely be caused by different factors like the approximation used to fill the incomplete overlap area, the uncertainties in data used as input (large differences shown in the $N_{2}$ scheme could be due the uncertainties associated with the measurements of relative lunar sky radiance), the self-uncertainties of the GRASP algorithm under the configurations implemented but also the uncertainty in the values used as reference (like uncertainties in the in situ measurements), the lack of overlap between night-time retrievals and AERONET daytime retrievals used as reference, and possible inhomogeneity in the atmosphere and local aerosol sources when the GRASP retrievals are compared with in situ measurements carried out in the mountains.

The analysis presented here is useful to present three configurations of the GRASP algorithm to retrieve night-time column-integrated and vertically resolved aerosol properties by a combination of different remote-sensing instruments. In fact, the proposed $N_{2}$ scheme provides a stand-alone way to retrieve intensive and extensive aerosol properties at night in cases with high values of AOD and high Moon irradiance (at least between the first and last Moon quarters) independent of daytime information, even when this scheme usually presents higher differences than the reference values. However, this study is focuses on one aerosol episode which is representative of Saharan dust transport, and hence it is necessary to use a more complete data set that includes at least different aerosol types. Additional studies are needed in this regard to investigate the accuracy and uncertainty of the retrieved GRASP products obtained with the proposed schemes; in this sense sensitivity tests could be done using synthetic data as reference. Therefore, in future studies, it is planned to develop different sensitivity studies with the proposed schemes. In addition, we could try to study the capabilities of GRASP to work with Raman lidar signals and implement the multipixel scenario proposed by Dubovik et al. (2011) to retrieve the aerosol properties at night.

Data availability. The GRASP inversion algorithm software used in this work is free and publicly available at http://www.grasp-open. com (last access: 1 July 2019). Lidar, lunar photometer and in situ raw data are available from the authors upon request. Sunsky photometer data are accessible on the AERONET website (http: //aeronet.gsfc.nasa.gov/, last access: 25 July 2019).

Author contributions. JABO performed the GRASP retrievals, analysed the data and wrote the paper. RR processed the sky camera measurements and helped to perform GRASP retrievals. JACV and HL operated and processed the in situ measurements. The formal analysis, investigation, writing of the original draft, preparation, review of the writing and editing were performed by JABO, RR, DPR, JACV, HL and LAA. POA, AEBV, GdAM and JLGR operated the lidar and helped to calculate Raman profiles. AL, DF, MH, BT and OD provided feedback on the GRASP algorithm. AB and PG processed the night-time measurements of the sun-sky-lunar photome- ter. The project administration, funding acquisition and design of the SLOPE campaign were done by FJOR and LAA. All authors provided comments on the paper and helped with paper correction.

Competing interests. The authors declare that they have no conflict of interest.

Special issue statement. This article is part of the special issue "EARLINET aerosol profiling: contributions to atmospheric and climate research". It is not associated with a conference.

Acknowledgements. Jose Antonio Benavent-Oltra is funded by MINECO under the predoctoral programme FPI (BES-2014068893) and by the University of Granada through "Plan Propio. Programa 7, Convocatoria 2018" and "Plan Propio. Programa 7, Convocatoria 2019”. Roberto Román is funded by MINECO under the postdoctoral programme Juan de la Cierva-Incorporación (IJCI2016-30007). Juan Andrés Casquero-Vera is funded by MINECO under the predoctoral programme FPI (BES-2017-080015). Andrés Esteban Bedoya-Velásquez has been supported by a grant for $\mathrm{PhD}$ studies in Colombia, COLCIENCIAS (Doctorado Nacional 647), associated with the Physics Sciences programme at the Universidad Nacional de Colombia, Sede Medellín and the Asociación Universitaria Iberoamericana de Postgrado (AUIP). Oleg Dubovik was supported by the Labex CaPPA project, which is funded by the French National Research Agency under contract "ANR-11-LABX0005-01". GRASP evaluations were done during secondments funded by the Marie Skłodowska-Curie Research Innovation and Staff Exchange (RISE) GRASP-ACE (grant no. 778349) project. The authors thankfully acknowledge the FEDER programme for the instrumentation used in this work, the University of Granada, which supported this study through the excellence units programme, and the Sierra Nevada National Park. Thanks to AERONET and ACTRIS/AERONET-Europe for the scientific and technical support. Finally, the authors would like to acknowledge the use of the GRASP inversion algorithm software (http://www.grasp-open.com, last access: 1 July 2019) in this work.

Financial support. This research has been supported by the European Union through the H2020 programme (ACTRIS-2, grant no. 654109) and the Spanish Ministry of Economy and Competitiveness (projects CMT2015-66742-R, CGL2016-81092R, CGL2017-85344-R, RTI2018-097864-B-I00 and CGL201790884-REDT).

Review statement. This paper was edited by Eduardo Landulfo and reviewed by two anonymous referees. 


\section{References}

Alados-Arboledas, L., Muller, D., Guerrero-Rascado, J. L., NavasGuzman, F., Pérez-Ramírez, D., and Olmo, F. J.: Optical and microphysical properties of fresh biomass burning aerosol retrieved by Raman lidar, and star-and sun-photometry, Geophys. Res. Lett., 38, L01807, https://doi.org/10.1029/2010GL045999, 2011.

Anderson, T. L. and Ogren, J. A.: Determining aerosol radiative properties using the TSI 3563 integrating nephelometer, Aerosol Sci. Tech., 29, 57-69, 1998.

Andreae, M. O., Rosenfeld, D., Artaxo, P., Costa, A. A., Frank, G. P., Longo, K. M., and Silvas-Dias, M. A. F.: Smoking rain clouds over the Amazon, Science, 303, 1337-1342, 2004.

Ansmann, A., Riebesell, M., Wandinger, U., Weitkamp, C., Voss, E., Lahmann, W., and Michaelis, W.: Combined Raman elastic backscatter LIDAR vertical profiling of moisture, aerosol extinction, backscatter and LIDAR ratio, Appl. Phys. B, 55, 18-28, 1992.

Antuña-Marrero, J. C., Landulfo, E., Estevan, R., Barja, B., Robock, A., Wolfram, E., Ristori, P., Clemesha, B., Zaratti, F., Forno, R., Armandillo, E., Bastidas, Á. E., de Frutos Baraja, Á. M., Whiteman, D. N., Quel, E., Barbosa, H. M. J., Lopes, F., Montilla-Rosero, E., and Guerrero-Rascado, J. L.: LALINET: The First Latin American-Born Regional Atmospheric Observational Network, B. Am. Meteorol. Soc., 98, 1255-1275, https://doi.org/10.1175/BAMS-D-15-00228.1, 2017.

Baibakov, K., O’Neill, N. T., Ivanescu, L., Duck, T. J., Perro, C., Herber, A., Schulz, K.-H., and Schrems, O.: Synchronous polar winter starphotometry and lidar measurements at a High Arctic station, Atmos. Meas. Tech., 8, 3789-3809, https://doi.org/10.5194/amt-8-3789-2015, 2015.

Barreto, A., Cuevas, E., Damiri, B., Guirado, C., Berkoff, T., Berjón, A. J., Hernández, Y., Almansa, F., and Gil, M.: A new method for nocturnal aerosol measurements with a lunar photometer prototype, Atmos. Meas. Tech., 6, 585-598, https://doi.org/10.5194/amt-6-585-2013, 2013.

Barreto, Á., Cuevas, E., Granados-Muñoz, M. J., Alados-Arboledas, L., Romero, P. M., Gröbner, J., Kouremeti, N., Almansa, A. F., Stone, T., Toledano, C., Román, R., Sorokin, M., Holben, B., Canini, M., and Yela, M.: The new sun-skylunar Cimel CE318-T multiband photometer - a comprehensive performance evaluation, Atmos. Meas. Tech., 9, 631-654, https://doi.org/10.5194/amt-9-631-2016, 2016.

Barreto, Á., Román, R., Cuevas, E., Pérez-Ramírez, D., J. Berjón, A., Kouremeti, N., Kazadzis, S., Gröbner, J., Mazzola, M., Toledano, C., Benavent-Oltra, J. A., Doppler, L., Juryšek, J., Almansa, A. F., Victori, S., Maupin, F., Guirado-Fuentes, C., González, R., Vitale, V., Goloub, P., Blarel, L., Alados-Arboledas, L., Woolliams, E., Greenwell, C., Taylor, S., Antuña, J. C., and Yela, M.: Evaluation of night-time aerosols measurements and lunar irradiance models in the frame of the first multi-instrument nocturnal intercomparison campaign, Atmos. Environ., 202, 190-211, https://doi.org/10.1016/j.atmosenv.2019.01.006, 2019.

Bedoya-Velásquez, A. E., Navas-Guzmán, F., Granados-Muñoz, M. J., Titos, G., Román, R., Casquero-Vera, J. A., Ortiz-Amezcua, P., Benavent-Oltra, J. A., de Arruda Moreira, G., MontillaRosero, E., Hoyos, C. D., Artiñano, B., Coz, E., Olmo-Reyes, F. J., Alados-Arboledas, L., and Guerrero-Rascado, J. L.: Hy- groscopic growth study in the framework of EARLINET during the SLOPE I campaign: synergy of remote sensing and in situ instrumentation, Atmos. Chem. Phys., 18, 7001-7017, https://doi.org/10.5194/acp-18-7001-2018, 2018.

Benavent-Oltra, J. A., Román, R., Granados-Muñoz, M. J., PérezRamírez, D., Ortiz-Amezcua, P., Denjean, C., Lopatin, A., Lyamani, H., Torres, B., Guerrero-Rascado, J. L., Fuertes, D., Dubovik, O., Chaikovsky, A., Olmo, F. J., Mallet, M., and Alados-Arboledas, L.: Comparative assessment of GRASP algorithm for a dust event over Granada (Spain) during ChArMExADRIMED 2013 campaign, Atmos. Meas. Tech., 10, 44394457, https://doi.org/10.5194/amt-10-4439-2017, 2017.

Berkoff, T. A., Sorokin, M., Stone, T., Eck, T. F., Hoff, R., Welton, E. J., and Holben, B.: Nocturnal aerosol optical depth measurements with a small-aperture automated photometer using the moon as a light source, J. Atmos. Ocean. Tech., 28, 1297-1306, 2011.

Böckmann, C.: Hybrid regularization method for the ill-posed inversion of multiwavelength lidar data to determine aerosol size distributions, Appl. Optics, 40, 1329-1342, 2001.

Boucher, O., Randall, D., Artaxo, P., Bretherton, C., Feingold, G., Forster, P., Kerminen, V.-M., Kondo, Y., Liao, H., Lohmann, U., Rasch, P., Satheesh, S. K., Sherwood, S., Stevens, B., and Zhang, X. Y.: Clouds and Aerosols, in: Climate Change 2013: The Physical Science Basis, Contribution of Working Group I to the Fifth Assessment Report of the Intergovernmental Panel on Climate Change, edited by: Stocker, T. F., Qin, D., Plattner, G.-K., Tignor, M., Allen, S. K., Boschung, J., Nauels, A., Xia, Y., Bex, V., and Midgley, P. M., Cambridge University Press, Cambridge, UK and New York, USA, 571-657, 2013.

Bovchaliuk, V., Goloub, P., Podvin, T., Veselovskii, I., Tanre, D., Chaikovsky, A., Dubovik, O., Mortier, A., Lopatin, A., Korenskiy, M., and Victori, S.: Comparison of aerosol properties retrieved using GARRLiC, LIRIC, and Raman algorithms applied to multi-wavelength lidar and sun/sky-photometer data, Atmos. Meas. Tech., 9, 3391-3405, https://doi.org/10.5194/amt-9-33912016, 2016.

Carlson, T. N. and Benjamin, S. G.: Radiative heating rates of Saharan dust, J. Atmos. Sci., 37, 193-213, 1980.

Chaikovsky, A., Dubovik, O., Goloub, P., Balashevich, N., Lopatsin, A., Karol, Y., Denisov, S., and Lapyonok, T.: Software package for the retrieval of aerosol microphysical properties in the vertical column using combined lidar/photometer data (test version), Technical Report, Institute of Physics, National Academy of Sciences of Belarus, Minsk, Belarus, 2008.

Chaikovsky, A., Dubovik, O., Holben, B., Bril, A., Goloub, P., Tanré, D., Pappalardo, G., Wandinger, U., Chaikovskaya, L., Denisov, S., Grudo, J., Lopatin, A., Karol, Y., Lapyonok, T., Amiridis, V., Ansmann, A., Apituley, A., Allados-Arboledas, L., Binietoglou, I., Boselli, A., D'Amico, G., Freudenthaler, V., Giles, D., Granados-Muñoz, M. J., Kokkalis, P., Nicolae, D., Oshchepkov, S., Papayannis, A., Perrone, M. R., Pietruczuk, A., Rocadenbosch, F., Sicard, M., Slutsker, I., Talianu, C., De Tomasi, F., Tsekeri, A., Wagner, J., and Wang, X.: Lidar-Radiometer Inversion Code (LIRIC) for the retrieval of vertical aerosol properties from combined lidar/radiometer data: development and distribution in EARLINET, Atmos. Meas. Tech., 9, 1181-1205, https://doi.org/10.5194/amt-9-1181-2016, 2016. 
Chen, C., Dubovik, O., Henze, D. K., Lapyonak, T., Chin, M., Ducos, F., Litvinov, P., Huang, X., and Li, L.: Retrieval of desert dust and carbonaceous aerosol emissions over Africa from POLDER/PARASOL products generated by the GRASP algorithm, Atmos. Chem. Phys., 18, 12551-12580, https://doi.org/10.5194/acp-18-12551-2018, 2018.

de Arruda Moreira, G., Guerrero-Rascado, J. L., Bravo-Aranda, J. A., Benavent-Oltra, J. A., Ortiz-Amezcua, P., Román, R., Bedoya-Velásquez, A. E., Landulfo, E., and AladosArboledas, L.: Study of the planetary boundary layer by microwave radiometer, elastic lidar and Doppler lidar estimations in Southern Iberian Peninsula, Atmos. Res., 213, 185-195, https://doi.org/10.1016/j.atmosres.2018.06.007, 2018.

de Arruda Moreira, G., Guerrero-Rascado, J. L., Benavent-Oltra, J. A., Ortiz-Amezcua, P., Román, R. E., Bedoya-Velásquez, A., Bravo-Aranda, J. A., Olmo Reyes, F. J., Landulfo, E., and Alados-Arboledas, L.: Analyzing the turbulent planetary boundary layer by remote sensing systems: the Doppler wind lidar, aerosol elastic lidar and microwave radiometer, Atmos. Chem. Phys., 19, 1263-1280, https://doi.org/10.5194/acp-191263-2019, 2019.

Dubovik, O.: Optimization of Numerical Inversion in Photopolarimetric Remote Sensing, in: Photopolarimetry in Remote Sensing, edited by: Videen, G., Yatskiv, Y., and Mishchenko, M., Kluwer Academic Publishers, Dordrecht, the Netherlands, 65106, 2004.

Dubovik, O. and King, M.: A flexible inversion algorithm for retrieval of aerosol optical properties from Sun and sky radiance measurements, J. Geophys. Res., 105, 20673-20696, https://doi.org/10.1029/2000JD900282, 2000.

Dubovik, O., Smirnov, A., Holben, B. N., King, M. D., Kaufman, Y., Eck, T. F., and Slutsker, I.: Accuracy assessments of aerosol optical properties retrieved from AerosolRobotic Network (AERONET) Sun and sky radiance measurements, J. Geophys. Res., 105, 9791-9806, 2000.

Dubovik, O., Holben, B., Eck, T., Smirnov, A., Kaufman, Y., King, M., Tanre, D., and Slutsker, I.: Variability of absorption and optical properties of key aerosol types observed in worldwide locations, J. Atmos. Sci., 59, 590-608, 2002.

Dubovik, O., Sinyuk, A., Lapyonok, T., Holben, B. N., Mishchenko, M., Yang, P., Eck, T. F., Volten, H., Munoz, O., Veihelmann, B., van der Zande, W. J., Leon, J.-F., Sorokin, M., and Slutsker, I.: Application of spheroid models to account for aerosol particle nonsphericity in remote sensing of desert dust, J. Geophys. Res., 111, D11208, https://doi.org/10.1029/2005JD006619, 2006.

Dubovik, O., Herman, M., Holdak, A., Lapyonok, T., Tanré, D., Deuzé, J. L., Ducos, F., Sinyuk, A., and Lopatin, A.: Statistically optimized inversion algorithm for enhanced retrieval of aerosol properties from spectral multi-angle polarimetric satellite observations, Atmos. Meas. Tech., 4, 975-1018, https://doi.org/10.5194/amt-4-975-2011, 2011.

Dubovik, O., Lapyonok, T., Litvinov, P., Herman, M., Fuertes, D., Ducos, F., Lopatin, A., Chaikovsky, A., Torres, B., Derimian, Y., Huang, X., Aspetsberger, M., and Federspiel, C.: GRASP: A Versatile Algorithm for Characterizing the Atmosphere, SPIE Newsroom, https://doi.org/10.1117/2.1201408.005558, 2014.

Dubovik, O., Li, Z., Mishchenko, M. I., Tanré, D., Karol, Y., Bojkov, B., Cairns, B., Diner, D. J., Espinosa, W. R., Goloub, P., Gu, X., Hasekamp, O., Hong, J., Hou, W., Knobelspiess, K.
D., Landgraf, J., Li, L., Litvinov, P., Liu, Y., Lopatin, A., Marbach, T., Maring, H., Martins, V., Meijer, Y., Milinevsky, G., Mukai, S., Parol, F., Qiao, Y., Remer, L., Rietjens, J., Sano, I., Stammes, P., Stamnes, S., Sun, X., Tabary, P., Travis, L. D., Waquet, F., Xu, F., Yan, C., and Yin, D.: Polarimetric remote sensing of atmospheric aerosols: Instruments, methodologies, results, and perspectives, J. Quant. Spectrosc. Ra., 224, 474-511, https://doi.org/10.1016/j.jqsrt.2018.11.024, 2019.

Espinosa, W. R., Remer, L. A., Dubovik, O., Ziemba, L., Beyersdorf, A., Orozco, D., Schuster, G., Lapyonok, T., Fuertes, D., and Martins, J. V.: Retrievals of aerosol optical and microphysical properties from Imaging Polar Nephelometer scattering measurements, Atmos. Meas. Tech., 10, 811-824, https://doi.org/10.5194/amt-10-811-2017, 2017.

Fedarenka, A., Dubovik, O., Goloub, P., Li, Z., Lapyonok, T., Litvinov, P., Blarel, L., Gonzalez, L., Podvin, T., Crozel, D.: Utilization of AERONET polarimetric measurements for improving retrieval of aerosol microphysics: GSFC, Beijing and Dakar data analysis, J. Quant. Spectrosc. Ra., 179, 72-97, 2016.

Fernald, F. G., Herman, B. M., and Reagan, J. A.: Determination of aerosol height distributions by lidar, J. Appl. Meteorol., 11, 482-489, 1972.

Fernald, F. G.: Analysis of atmospheric lidar observations - Some comments, Appl. Optics, 23, 652-653, 1984.

Fernández, A. J., Sicard, M., Costa, M. J., Guerrero-Rascado, J. L., Gómez-Amo, J. L., Molero, F., Barragán, R., Basart, S., Bortoli, D., Bedoya-Velásquez, A. E., Utrillas, M. P., Salvador, P., Granados-Muñoz, M. J., Potes, M., Ortiz-Amezcua, P., MartínezLozano, J. A., Artíñano, B., Muñoz-Porcar, C., Salgado, R., Román, R., Rocadenbosch, F., Salgueiro, V., Benavent-Oltra, J. A., Rodríguez-Gómez, A., Alados-Arboledas, L., Comerón, A., and Pujadas, M.: Extreme, wintertime Saharan dust intrusion in the Iberian Peninsula: Lidar monitoring and evaluation of dust forecast models during the February 2017 event, Atmos. Res., 228, 223-241, https://doi.org/10.1016/j.atmosres.2019.06.007, 2019.

González, Y., Lopez, C., and Cuevas, E.: Automatic observation of cloudiness: analysis ofall sky images, TECO-2012, in: WMO Technical Conference on Meteorological and Environmental Instruments and Methods of Observation, 16-18 October 2012 Brussels, Belgium, 2012.

Granados-Muñoz, M. J., Sicard, M., Román, R., Benavent-Oltra, J. A., Barragán, R., Brogniez, G., Denjean, C., Mallet, M., Formenti, P., Torres, B., and Alados-Arboledas, L.: Impact of mineral dust on shortwave and longwave radiation: evaluation of different vertically resolved parameterizations in 1-D radiative transfer computations, Atmos. Chem. Phys., 19, 523-542, https://doi.org/10.5194/acp-19-523-2019, 2019.

Guerrero-Rascado, J. L., Ruiz, B., and Alados Arboledas, L.: Multispectral Lidar characterization of the vertical structure of Saharan dust aerosol over southern Spain, Atmos. Environ., 42, 26682681, https://doi.org/10.1016/j.atmosenv.2007.12.062, 2008.

Guerrero-Rascado, J. L., Olmo, F. J., Avilés-Rodríguez, I., NavasGuzmán, F., Pérez-Ramírez, D., Lyamani, H., and Alados Arboledas, L.: Extreme Saharan dust event over the southern Iberian Peninsula in September 2007: active and passive remote sensing from surface and satellite, Atmos. Chem. Phys., 9, 84538469, https://doi.org/10.5194/acp-9-8453-2009, 2009. 
Guerrero-Rascado, J. L., Landulfo, E., Antuña, J. C., Barbosa, H. M. J., Barja, B., Bastidas, A. E., Bedoya, A. E., da Costa, R. F., Estevan, R., Forno, R. N., Gouveia, D. A., Jimenez, C., Larroza, E. G., Lopes, F. J. S., Montilla-Rosero, E., Moreira, G. A., Nakaema, W. M., Nisperuza, D., Alegria, D., Múnera, M., Otero, L., Papandrea, S., Pawelko, E., Quel, E. J., Ristori, P., Rodrigues, P. F., Salvador, J., Sánchez, M. F., and Silva, A.: Latin American Lidar Network (LALINET) for aerosol research: diagnosis on network instrumentation, J Atmos. Sol.-Terr. Phy., 138-139, 112-120, 2016.

Herreras, M., Román, R., Cazorla, A., Toledano, C., Lyamani, H., Torres, B., Cachorro, V. E., Olmo, F. J., Alados-Arboledas, L., and de Frutos, A. M.: Evaluation of retrieved aerosol extinction profiles using as reference the aerosol optical depth differences between various heights, Atmos. Res., 230, 104625, https://doi.org/10.1016/j.atmosres.2019.104625, 2019.

Holben, B. N., Eck, T. F., Slutsker, I., Tanre, D., Buis, J. P., Setzer, A., Vermote, E., Reagan, J. A., Kaufman, Y. J., Nakajima, T., Lavenu, F., Jankowiak, I., and Smirnov, A.: AERONET-a federated instrument network a data archive for aerosol characterization, Remote Sens. Environ., 66, 1-16, 1998.

Holben, B. N., Eck, T. F., Slutsker, I., Smirnov, A., Sinyuk, A., Schafer, J., Giles, D., and Dubovik, O.: AERONET's Version 2.0 Quality Assurance Criteria, Remote Sensing of the Atmosphere and Clouds, Proc. SPIE, 6408, 64080Q, https://doi.org/10.1117/12.706524, 2006.

Horvath, H., Alados Arboledas, L., and Olmo Reyes, F. J.: Angular scattering of the Sahara dust aerosol, Atmos. Chem. Phys., 18, 17735-17744, https://doi.org/10.5194/acp-18-177352018, 2018.

IPCC - Intergovernmental Panel on Climate Change: Contribution of Working Group I to the Fifth Assessment Report of the Intergovernmental Panel on Climate Change, in: Summary for Poli-cymakers in Climate Change, edited by: Stocker, T. F., Qin, D.,Plattner, G.-K., Tignor, M., Allen, S. K., Boschung, J., Nauels,A., Xia, Y., Bex, V., and Midgley, P. M., Cambridge Univ. Press, New York, USA, 590-600, 2013.

Klett, J. D.: Stable analytical inversion solution for processing lidar returns, Appl. Optics, 20, 211-220, 1981.

Klett, J. D.: Lidar inversion with variable backscatter/extinction ratios, Appl. Optics, 24, 1638-1643, 1985.

Koepke, P., Hess, M., Schult, I., and Shettle, E. P.: Global aerosol data set, MPI Meteorologie Hamburg Rep. 243, MPI, Hamburg, 44 pp., 1997.

Kokhanovsky, A. A., Davis, A. B., Cairns, B., Dubovik, O., Hasekamp, O. P., Sano, I., Mukai, S., Rozanov, V. V., Litvinov, P., Lapyonok, T., Kolomiets, I. S., Oberemok, Y. A., Savenkov, S., Martin, W., Wasilewski, A., Di Noia, A., Stap, F. A., Rietjens, J., Xu, F., Natraj, V., Duan, M., Cheng, T., and Munro, R.: Space-based remote sensing of atmospheric aerosols: the multiangle spectro-polarimetric frontier, Earth Sci. Rev., 145, 85-116, 2015.

Lopatin, A., Dubovik, O., Chaikovsky, A., Goloub, P., Lapyonok, T., Tanré, D., and Litvinov, P.: Enhancement of aerosol characterization using synergy of lidar and sun-photometer coincident observations: the GARRLiC algorithm, Atmos. Meas. Tech., 6, 2065-2088, https://doi.org/10.5194/amt-6-2065-2013, 2013.

Lyamani, H., Olmo, F. J., and Alados-Arboledas, L.: Saharan dust outbreak over southeastern Spain as detected by sun photometer, Atmos. Environ., 39, 7276-7284, https://doi.org/10.1016/j.atmosenv.2005.09.011, 2005.

Lyamani, H., Olmo, F. J., Alcantara, A., and Alados-Arboledas, L.: Atmospheric aerosols during the 2003 heat wave in southeastern spain I: Spectral optical depth, Atmos. Environ., 40, 6453-6464, https://doi.org/10.1016/j.atmosenv.2006.04.048, 2006.

Lyamani, H., Olmo, F. J., and Alados-Arboledas, L.: Physical and optical properties of aerosols over an urban location in Spain: seasonal and diurnal variability, Atmos. Chem. Phys., 10, 239254, https://doi.org/10.5194/acp-10-239-2010, 2010.

Müller, D., Wandinger, U., and Ansmann, A.: Microphysical particle parameters from extinction and backscatter lidar data by inversion with regularization: simulation, Appl. Optics, 38, 23582368, 1999.

Nakajima, T., Tonna, G., Rao, R., Boi, P., Kaufman, Y., and Holben, B.: Use of sky brightness measurements from ground for remote sensing of particulate polydispersions, Appl. Optics, 35, 2672 2686, https://doi.org/10.1364/AO.35.002672, 1996.

Nakajima, T., Yoon, S. C., Ramanathan, V., Shi, G. Y., Takemura, T., Higurashi, A., Takamura, T., Aoki, K., Sohn, B. J., Kim, S. W., Tsuruta, H., Sugimoto, N., Shimizu, A., Tanimoto, H., Sawa, Y., Lin, N. H., Lee, C. T., Goto, D., and Schutgens, N.: Overview of the Atmospheric Brown Cloud East Asian Regional Experiment 2005 and a study of the aerosol direct radiative forcing in east Asia, J. Geophys. Res., 112, D24S91, https://doi.org/10.1029/2007JD009009, 2007.

Navas-Guzmán, F., Guerrero-Rascado, J. L., and Alados-Arboledas, L.: Retrieval of the lidar overlap function using Raman signals, Opt. Pure Appl., 44, 71-75, 2011.

Ortiz-Amezcua, P., Guerrero-Rascado, J. L., Granados-Muñoz, M. J., Benavent-Oltra, J. A., Böckmann, C., Samaras, S., Stachlewska, I. S., Janicka, L., Baars, H., Bohlmann, S., and AladosArboledas, L.: Microphysical characterization of long-range transported biomass burning particles from North America at three EARLINET stations, Atmos. Chem. Phys., 17, 5931-5946, https://doi.org/10.5194/acp-17-5931-2017, 2017.

Pappalardo, G., Amodeo, A., Apituley, A., Comeron, A., Freudenthaler, V., Linné, H., Ansmann, A., Bösenberg, J., D’Amico, G., Mattis, I., Mona, L., Wandinger, U., Amiridis, V., AladosArboledas, L., Nicolae, D., and Wiegner, M.: EARLINET: towards an advanced sustainable European aerosol lidar network, Atmos. Meas. Tech., 7, 2389-2409, https://doi.org/10.5194/amt7-2389-2014, 2014.

Patrón, D., Lyamani, H., Titos, G., Casquero-Vera, J. A., Cardell, C., Močnik, G., Alados-Arboledas, L., and Olmo, F. J.: Monumental heritage exposure to urban black carbon pollution, Atmos. Environ., 170, 22-32, https://doi.org/10.1016/j.atmosenv.2017.09.030, 2017.

Patterson, E. M., Gillette, D. A., and Stockton, B. H.: Complex index of refraction between 300 and 700 for Saharan aerosols, J. Geophys. Res., 82, 3153-3160, 1977.

Pérez-Ramírez, D., Lyamani, H., Olmo, F. J., and Alados Arboledas, L.: Improvements in star photometry for aerosol characterizations, J. Aerosol Sci., 4, 737-745, 2011.

Pérez-Ramírez, D., Lyamani, H., Olmo, F. J., Whiteman, D. N., and Alados-Arboledas, L.: Columnar aerosol properties from sun-and-star photometry: statistical comparisons and day-to-night dynamic, Atmos. Chem. Phys., 12, 9719-9738, https://doi.org/10.5194/acp-12-9719-2012, 2012. 
Pérez-Ramírez, D., Veselovskii, I., Whiteman, D. N., Suvorina, A., Korenskiy, M., Kolgotin, A., Holben, B., Dubovik, O., Siniuk, A., and Alados-Arboledas, L.: High temporal resolution estimates of columnar aerosol microphysical parameters from spectrum of aerosol optical depth by linear estimation: application to long-term AERONET and sta-photometry measurements, Atmos. Meas. Tech., 8, 3117-3133, https://doi.org/10.5194/amt-83117-2015, 2015.

Pérez-Ramírez, D., Lyamani, H., Smirnov, A., O’Neill, N. T., Veselovskii, I., Whiteman, D. N., Olmo, F. J., and Alados-Arboledas, L.: Statistical study of day and night hourly patterns of columnar aerosol properties using sun and star photometry, Proc. SPIE, 100001, 100010K, https://doi.org/10.1117/12.2242372, 2016.

Rolph, G. D.: Real-time Environmental Applications and Display sYstem (READY) Website (http://www.ready.noaa.gov), NOAA Air Resources Laboratory, College Park, MD, 2016.

Román, R., Torres, B., Fuertes, D., Cachorro, V. E., Dubovik, O., Toledano, C., Cazorla, A., Barreto, A., Bosch, J. L., Lapyonok,T, González, R., Goloub, P., Perrone, M. R., Olmo, F. J., de Frutos, A., and Alados-Arboledas, L.: Remote sensing of lunar aureole with a sky camera: Adding information in the nocturnal retrieval of aerosol properties with GRASP code, Remote Sens. Environ., 196, 238-252, https://doi.org/10.1016/j.rse.2017.05.013, 2017a.

Román, R., Cazorla, A., Toledano, C., Olmo, F. J., Cachorro, V. E., de Frutos, A., and Alados-Arboledas, L.: Cloud cover detection combining high dynamic range sky images and ceilometer measurements, Atmos. Res., 196, 224-236, https://doi.org/10.1016/j.atmosres.2017.06.006, 2017b.

Román, R., Benavent-Oltra, J. A., Casquero-Vera, J. A., Lopatin, A., Cazorla, A., Lyamani, H., Denjean, C., Fuertes, D., PérezRamírez, D., Torres, B., Toledano, C., Dubovik, O., Cachorro, V. E., de Frutos, Á., Olmo, F. J., and Alados-Arboledas, L.: Retrieval of aerosol profiles combining sunphotometer and ceilometer measurements in GRASP code, Atmos. Res., 204, 161-177, https://doi.org/10.1016/j.atmosres.2018.01.021, 2018.

Shettle, E. P. and Fenn, R. W.: Models of aerosols of lower troposphere and the effect of humidity variations on their optical properties, AFCRL Tech. Rep. 79 0214, Air Force Cambridge Research Laboratory, Hanscom Air Force Base, MA, 100 pp., 1979.

Sicard, M., Granados-Muñoz, M. J., Alados-Arboledas, L., Barragán, R., Bedoya-Velásquez, A. E., Benavent-Oltra, J. A., Bortoli, D., Comerón, A., Córdoba-Jabonero, C., Costa, M. J., del Águila, A., Fernández, A. J., Guerrero-Rascado, J. L., Jorba, O., Molero, F., Muñoz-Porcar, C., Ortiz-Amezcua, P., Papagiannopoulos, N., Potes, M., Pujadas, M., Rocadenbosch, F., Rodríguez-Gómez, A., Román, R., Salgado, R., Salgueiro, V., Sola, Y., and Yela, M.: Ground/space, passive/active remote sensing observations coupled with particle dispersion modelling to understand the inter-continental transport of wildfire smoke plumes, Remote Sens. Environ., 232, 111294, https://doi.org/10.1016/j.rse.2019.111294, 2019.

Sokolik, I. N. and Toon, O. B. Incorporation of mineralogical composition into models of the radiative properties of mineral aerosol from UV to IR wavelengths, J. Geophys. Res., 104, 9423-9444, 1999.
Sokolik, I. N., Andronove, A., and Johnson, T. C.: Complex refractive index of atmospheric dust aerosols, Atmos. Environ., 27A, 2495-2502, 1993.

Sorribas, M., Olmo, F. J., Quirantes, A., Lyamani, H., GilOjeda, M., Alados-Arboledas, L., and Horvath, H.: Role of spheroidal particles in closure studies for aerosol microphysicaloptical properties, Q. J. Roy. Meteorol. Soc., 141, 2700-2707, https://doi.org/10.1002/qj.2557, 2015.

Soupiona, O., Samaras, S., Ortiz-Amezcua, P., Böckmann, C., Papayannis, A., Moreira, G. A., Benavent-Oltra, J. A., GuerreroRascado, J. L., Bedoya-Velásquez, A. E., Olmo, F. J., Román, R., Kokkalis, P., Mylonaki, M., Alados-Arboledas, L., Papanikolaou, C. A., and Foskinisa, R.: Retrieval of optical and microphysical properties of transported Saharan dust over Athens and Granada based on multi-wavelength Raman lidar measurements: Study of the mixing processes, Atmos. Environ., 214, 190-211, https://doi.org/10.1016/j.atmosenv.2019.116824, 2019.

Stein, A. F., Draxler, R. R., Rolph, G. D., Stunder, B. J. B., Cohen, M. D., and Ngan, F.: NOAA's HYSPLIT atmospheric transport and dispersion modeling system, B. Am. Meteorol. Soc., 96, 2059-2077, 2015.

Torres, B., Dubovik, O., Fuertes, D., Schuster, G., Cachorro, V. E., Lapyonok, T., Goloub, P., Blarel, L., Barreto, A., Mallet, M., Toledano, C., and Tanré, D.: Advanced characterisation of aerosol size properties from measurements of spectral optical depth using the GRASP algorithm, Atmos. Meas. Tech., 10, 3743-3781, https://doi.org/10.5194/amt-10-3743-2017, 2017.

Tsekeri, A., Lopatin, A., Amiridis, V., Marinou, E., Igloffstein, J., Siomos, N., Solomos, S., Kokkalis, P., Engelmann, R., Baars, H., Gratsea, M., Raptis, P. I., Binietoglou, I., Mihalopoulos, N., Kalivitis, N., Kouvarakis, G., Bartsotas, N., Kallos, G., Basart, S., Schuettemeyer, D., Wandinger, U., Ansmann, A., Chaikovsky, A. P., and Dubovik, O.: GARRLiC and LIRIC: strengths and limitations for the characterization of dust and marine particles along with their mixtures, Atmos. Meas. Tech., 10, 4995-5016, https://doi.org/10.5194/amt-10-4995-2017, 2017.

Valenzuela, A., Olmo, F. J., Lyamani, H., Antón, M., Quirantes, A., and Alados-Arboledas, L.: Classification of aerosol radiative properties during African desert dust intrusions over southeastern Spain by sector origins and cluster analysis, J. Geophys. Res., 117, D06214, https://doi.org/10.1029/2011JD016885, 2012.

Veselovskii, I., Kolgotin, A., Griaznov, V., Muller, D., Wandinger, U., and Whiteman, D: Inversion with regularization for the retrieval of tropospheric aerosol parameters from multiwavelength lidar sounding, Appl.Optics, 41, 3685-3699, 2002.

Veselovskii, I., Kolgotin, A., Muller, D., and Whiteman, D.: Information content of multiwavelength lidar data with respect to microphysical particle properties derived from eigenvalue analysis, Appl. Optics, 44, 5292-5303, 2005.

Wagner, R., Ajtai, T., Kandler, K., Lieke, K., Linke, C., Müller, T., Schnaiter, M., and Vragel, M.: Complex refractive indices of Saharan dust samples at visible and near UV wavelengths: a laboratory study, Atmos. Chem. Phys., 12, 2491-2512, https://doi.org/10.5194/acp-12-2491-2012, 2012.

Welton, E. J., Voss, K. J., Quinn, P. K., Flatau, P. J., Markowicz, K., Campbell, J. R., Spinhirne, J. D., Gordon, H. R., and Johnson, J. E.: Measurements of aerosol vertical profiles and optical properties during INDOEX 1999 using micropulse lidars, J. Geophys. Res., 107, 18-1-18-20, 2002. 
Whiteman, D. N., Melfi, S. H., and Ferrare, R. A.: Raman lidar system for the measurement of water vapor and aerosols in the Earth's atmosphere, Appl. Optics, 31, 3068-3082, 1992.

Wiedensohler, A., Birmili, W., Nowak, A., Sonntag, A., Weinhold, K., Merkel, M., Wehner, B., Tuch, T., Pfeifer, S., Fiebig, M., Fjäraa, A. M., Asmi, E., Sellegri, K., Depuy, R., Venzac, H., Villani, P., Laj, P., Aalto, P., Ogren, J. A., Swietlicki, E., Williams, P., Roldin, P., Quincey, P., Hüglin, C., Fierz-Schmidhauser, R., Gysel, M., Weingartner, E., Riccobono, F., Santos, S., Grüning, C., Faloon, K., Beddows, D., Harrison, R., Monahan, C., Jennings, S. G., O’Dowd, C. D., Marinoni, A., Horn, H.-G., Keck, L., Jiang, J., Scheckman, J., McMurry, P. H., Deng, Z., Zhao, C. S., Moerman, M., Henzing, B., de Leeuw, G., Löschau, G., and Bastian, S.: Mobility particle size spectrometers: harmonization of technical standards and data structure to facilitate high quality long-term observations of atmospheric particle number size distributions, Atmos. Meas. Tech., 5, 657-685, https://doi.org/10.5194/amt-5-657-2012, 2012.
WMO: Radiation commission of IAMAP meeting of experts on aerosol and their climatic effects, World Meteorological Organization Rep. WCP55, available at: https://library.wmo.int (last access: 1 July 2019), 28-30, 1983. 